Zabytkoznawstwo i Konserwatorstwo LII (2021)

\title{
Malarka (nie)zwykła Wanda Gentil-Tippenhauer i jej związki z międzywojenną Bydgoszczą
}

\author{
ANNA NADOLSKA \\ Muzeum Okręgowe im. Leona Wyczółkowskiego w Bydgoszczy \\ / Uniwersytet Kazimierza Wielkiego w Bydgoszczy \\ e-mail: anna.nadolska@muzeum.bydgoszcz.pl \\ ORCID 0000-0002-4063-7431
}

Keywords: Wanda Gentil-Tippenhauer, women painter, Bydgoszcz, exhibition, museum collections, Municipal Museum in Bydgoszcz

Słowa kluczowe: Wanda Gentil-Tippenhauer, malarka, Bydgoszcz, wystawiennictwo, zbiory muzealne, bydgoskie Muzeum Miejskie

\begin{abstract}
An (Un)Usual Woman Painter. Wanda Gentil-Tippenhauer and her Connections with Bydgoszcz during the Interwar Period

Wanda Gentil-Tippenhauer is mainly associated with Zakopane art. However, before settling down in the capital city of the Tatra Mountains this painter and mountain fan, born in exotic Haiti, during the interwar period had private and professional connections with Bydgoszcz. In the city on the Brda River, she lived with her mother and sister and participated in activities of the Bydgoszcz artistic milieu. Among her legacy one can find artworks that were inspired by beautiful views and Bydgoszcz architecture. Her watercolours were presented with success at exhibitions organized by the local Municipal Museum, especially during the "Exhibition of Polish Women Artists" (1930). After all these exhibitions her many paintings and a Batik scarves were acquired by the museum in Bydgoszcz. Gentil-Tippenhauer was one of the few female artists from Bydgoszcz that shaped the fine arts in the city during the $2^{\text {nd }}$
\end{abstract}


Polish Republic. The painter's undoubtedly close affiliations with the city on the Brda river remain unknown for most of Bydgoszcz inhabitants The activities of this (un)usual artist within the cultural life of interwar Bydgoszcz are worth discussing against the background of her broad artistic and literary activities and works of other women painters of that time.

\begin{abstract}
Abstrakt
Wanda Gentil-Tippenhauer kojarzona jest głównie z twórczością zakopiańską. Zanim ta urodzona na Haiti malarka i miłośniczka gór osiadła w stolicy Tatr, w okresie międzywojennym utrzymywała prywatne i zawodowe kontakty z Bydgoszczą. W mieście nad Brdą, gdzie mieszkała z matką i siostrą, brała udział w działalności bydgoskiego środowiska artystycznego. W jej dorobku twórczym można znaleźć prace plastyczne, do których inspirację czerpała z pięknych widoków i architektury Bydgoszczy. $\mathrm{Z}$ dużym powodzeniem prezentowała swoje akwarele i inne dzieła na wystawach organizowanych przez lokalne Muzeum Miejskie, z „Pierwszą wystawą artystek polskich” (1930) na czele; dzięki temu pozyskano kilka jej obrazów i chustę batikową do tutejszych zbiorów muzealnych. Gentil-Tippenhauer jest jedną z nielicznych artystek, które kreowały bydgoską plastykę w Drugiej Rzeczypospolitej, jednak bydgoszczanom związki, jakie niewątpliwie miała z miastem nad Brdą, pozostają właściwie nieznane. Warto omówić aktywność tej (nie)zwykłej artystki w życiu kulturalnym międzywojennej Bydgoszczy, jej działalność artystyczną i literacką - także na tle twórczości innych przedwojennych malarek.
\end{abstract}

Uznana artystka Wanda Gentil-Tippenhauer, dzisiaj kojarzona głównie z Zakopanem i pracami o tematyce górskiej, zanim zamieszkała w Warszawie, a potem w stolicy Tatr ${ }^{1}$, była związana z Bydgoszczą (il. 1). Należała w tym mieście do grona artystów tworzących lokalne środowisko plastyczne ${ }^{3}$. W czasach Drugiej Rzeczypospolitej niewiele kobiet profesjonalistek brało otwarcie udział w życiu artystycznym miasta, w dodatku większość z nich nie

1 Małgorzata Teichert, „Wanda Anna Gentil-Tippenhauer,” w Artystki polskie. Katalog wystawy, red. Agnieszka Morawińska (Warszawa: Muzeum Narodowe w Warszawie, 1991), 161.

2 Maria Karnkowska z Bartoszewiczów, „Wspomnienia cz. I i II”, wydano przez Kazimierza Karnkowskiego, Baden CH-5400 - czerwiec 2013, 78, file://C:/Users/Ania/Desktop/ Maria\%20Karnkowska\%20Wspomnienia\%20(1).PDF, dostęp 14 lipca 2020.

3 Polska Bydgoszcz 1920-1930. Dziesięć lat pracy twórczej (Bydgoszcz: Wydawnictwo Jubileuszowe Komitetu Obchodu Dziesięciolecia Oswobodzenia Miasta Bydgoszczy, 1930), 48; Kazimierz Borucki, „Plastyka bydgoska w latach 1920-1945,” w Bydgoszcz w latach 1920-1970. Materiały z sesji popularnonaukowej, red. Jerzy Konieczny i Edmund Trempała (Prace Popularnonaukowe 6) (Bydgoszcz: Bydgoskie Towarzystwo Naukowe, 1972), 255. 
przebywała w Bydgoszczy na stałe, a jedynie okresowo lub wręcz okazjonal$n^{4}{ }^{4}$. Instytucją mającą decydujący wpływ na rozwój międzywojennej plastyki bydgoskiej było Muzeum Miejskie ${ }^{5}$ - i wokół niego gromadzili się miejscowi malarze, graficy i rzeźbiarze, którzy chcieli tworzyć i pokazywać publiczności swoje dzieła ${ }^{6}$. Wśród nich była Wanda Gentil-Tippenhauer. Niegdyś sławna artystka jest w mieście nad Brdą zupełnie zapomniana; także w bydgoskiej historiografii jej nazwisko właściwie się nie pojawia, nie podają go nawet wytrawni badacze dziejów kultury miasta ${ }^{7}$. Z kolei biografowie Gentil-Tippenhauer odnotowali zaledwie pojedynczy udział artystki w bydgoskiej wystawie.

Warto zatem - po raz pierwszy, co należy podkreślić - omówić aktywność tej (nie)zwykłej malarki w życiu kulturalnym międzywojennej Bydgoszczy, jej działalność artystyczno-literacką i społeczną, również na tle twórczości innych przedwojennych artystek. Źródłową podstawą niniejszego szkicu są dokumenty zgromadzone przede wszystkim w Archiwum Państwowym w Bydgoszczy i w Bibliotece Muzeum Okręgowego im. Leona Wyczółkowskiego w Bydgoszczy, ponadto artykuły z lokalnej przedwojennej prasy, katalogi wystaw i zachowane wspomnienia. Uzupełniają je informacje pozyskane dzięki kwerendom przeprowadzonym w kilku krajowych placówkach muzealnych.

\section{Bydgoski dom - ul. Zamoyskiego}

Najpewniej artystka przybyła do miasta nad Brdą razem z matką, Wiktorią Gentil-Tippenhauer z domu Rosicką (1863-1946?), zawodową tłumaczką

4 Artystki mieszkające w Bydgoszczy: Elżbieta Śliwińska-Kapturkiewicz, Halina Magdańska-Dąbrowska, Jadwiga Przeradzka-Jędrzejewska, Zofia Plewińska-Smidowiczowa, Zofia Kulwieć, Wanda Winnicka, Wiktoria Goryńska.

5 Obecnie: Muzeum Okręgowe im. Leona Wyczółkowskiego w Bydgoszczy.

6 Zdzisław Hojka, Muzeum w Bydgoszczy. Dzieje i zbiory (Od kościoła Klarysek po Wyspę Młyńską. Muzeum w Bydgoszczy 1923-2008, red. Michał Woźniak, t. 1) (Bydgoszcz: Muzeum Okręgowe im. Leona Wyczółkowskiego, 2008), 14-25; szerzej Barbara Chojnacka, „Malarstwo w międzywojennej Bydgoszczy (1920-1939). Zapomniane dziedzictwo?,” w Stare i nowe dziedzictwo Torunia, Bydgoszczy i regionu, red. Juliusz Raczkowski i Monika Jakubek-Raczkowska (Studia i Materiały z Dziedzictwa Kulturowego Torunia i Regionu 2) (Toruń: Wydział Sztuk Pięknych UMK, 2018), 175-186.

7 Nie wymienia nazwiska Gentil-Tippenhauer Zdzisław Mrozek, „Polska kultura i sztuka w Bydgoszczy w latach 1920-1939," w Historia Bydgoszczy, t. 2, cz. 1 1920-1939, red. Marian Biskup (Bydgoszcz: Bydgoskie Towarzystwo Naukowe, 1999), 761-762. Obecnie Barbara Chojnacka przygotowuje opracowanie na temat bydgoskiego środowiska artystycznego w okresie międzywojennym, w którym przypomni omawianą artystkę. 
i pisarką, oraz młodszą siostrą Jadwigą ${ }^{8}$, około 1921 roku $^{9}$ (il. 2). Matka Wandy, która urodziła się w Łodzi a studiowała w Zurychu w Szwajcarii ${ }^{10}$, była jedyną w XIX wieku polską tłumaczką dzieła Williama Szekspira - przełożyła dramat Romeo i Julia ${ }^{11}$ - i pisała opowiadania dla dzieci. Po rozstaniu z mężem Louisem Wiepertem Gentil-Tippenhauerem i pobycie na Haiti wróciła do kraju. W bydgoskich księgach adresowych nazwisko Wiktorii figuruje w latach 1923-1926 oraz w 1933 i 1936 roku $^{12}$. Personalia jej córki Wandy zachowały się w dokumentach archiwalnych powstałych najprawdopodobniej w 1922 roku; podano w nich adres: „ul. Zamojskiego 8”, z czego wynika, że w tym czasie artystka mieszkała razem z matką ${ }^{13}$. Jednak w Bydgoszczy musiała przebywać sporadycznie, już bowiem po ukończeniu w 1921 roku Państwowych Kursów dla Nauczycieli Rysunków przy Szkole Sztuk Pięknych w Warszawie pod kierunkiem Karola Tichego, do roku 1923 studiowała w hamburskiej Kunstgewerbeschule ${ }^{14}$. Wiosną 1922 roku wzięła udział w bydgoskiej wystawie polskiej sekcji artystycznej Polskiego Instytutu Narodowego ${ }^{15}$, na której pokazała aż dziesięć prac: Jesienią, Martwa natura, Bałtyk, $W$ francuskim parku, W parku, O zachodzie, Wieś, Droga, Stóg, Jezioro ${ }^{16}$. Po ukończe-

8 Karnkowska z Bartoszewiczów, „Wspomnienia,” 78.

9 Już w styczniu 1922 r. Wanda Gentil-Tippenhauer deklamowała utwory podczas bydgoskiej imprezy kulturalnej, „Koncert piątkowy”, Dziennik Bydgoski, 17 stycznia 1922, 3.

10 Karnkowska z Bartoszewiczów, „Wspomnienia,” 78.

11 William Shakespeare, Romeo i Julia. Tragedya w 5 aktach, tłum. Wiktorya Rosicka (Łódź: Księgarnia L. Fischera, 1892); Anna Cetera-Włodarczyk i Alicja Kosim, Polskie przekłady Shakespeare'a w XIX wieku, cz. I Zasoby, strategie, recepcja (Warszawa: Wydawnictwa Uniwersytetu Warszawskiego, 2019), 365-369; „Polski Szekspir”, http://polskiszekspir.uw.edu.pl/ tlumacze, dostęp 8 marca 2021.

12 Ul. Zamojskiego 8: Adresy miasta Bydgoszczy na rok 1923 (Bydgoszcz: Władysław Weber, 1923), 618; Adresy miasta Bydgoszczy na rok 1925 (Bydgoszcz: Władysław Weber, 1925), 310; Adresy miasta Bydgoszczy na 1926 rok (Bydgoszcz: Władysław Weber, 1926), 85; ul. Zamojskiego 16/4: Księga adresowa m. Bydgoszczy 1933 rok (Bydgoszcz: Władysław Weber, 1933), 316; ul. Zamojskiego 15/4: Księga adresowa miasta Bydgoszczy rocznik 1936/1937 (Bydgoszcz: Jan Miernik, 1937), 532.

13 Archiwum Państwowe w Bydgoszczy (dalej: APB), Polskie legalne organizacje, związki, stowarzyszenia, towarzystwa i komitety 1920-1939, sygn. 479, nr 28, Wanda Gentil-Tippenhauer, b.p.

14 Anna Staniszewska, „Gentil-Tippenhauer Wanda Anna,” w Słownik artystów polskich i obcych $w$ Polsce działających. Malarze, rzeźbiarze, graficy, t. $2 D-G$, red. Jolanta Maurin-Białostocka i in. (Wrocław-Warszawa-Kraków-Gdańsk: Instytut Sztuki Polskiej Akademii Nauk / Zakład Narodowy im. Ossolińskich we Wrocławiu, 1975), 304; Teichert, „Wanda Anna Gentil-Tippenhauer," 161.

15 „Wystawa obrazów,” Dziennik Bydgoski, 12 kwietnia 1922, 3.

16 APB, Polskie legalne organizacje, związki, stowarzyszenia, towarzystwa i komitety 1920-1939, sygn. 479, nr 28, Wanda Gentil-Tippenhauer, b.p. 
niu edukacji artystycznej w czerwcu 1924 roku Wanda Gentil-Tippenhauer wyszła za mąż za Wacława Widigiera ${ }^{17}$ i zamieszkała w Warszawie ${ }^{18}$. Przeprowadzka do stolicy nie zakończyła jej kontaktów z Bydgoszczą - malarka przyjeżdżała do miasta nad Brdą i nadal brała udział w tutejszym życiu kulturalnym, prezentując swój dorobek twórczy na wystawach w Muzeum Miejskim w latach dwudziestych i trzydziestych XX wieku, a na jej akwarelach wielokrotnie gościła tematyka bydgoska ${ }^{19}$.

\section{Polskie artystki i ich twórczość}

W Drugiej Rzeczypospolitej, w odróżnieniu od czasów wcześniejszych, kobiety mogły kształcić się na kierunkach artystycznych na równi z mężczyznami20. Możliwości, jakie otrzymały - notabene wywalczone przez same kobiety szybko zaowocowały rozkwitem ich talentów artystycznych i umiejętności warsztatowych w każdej gałęzi sztuki: czy to było malarstwo, grafika, rysunek, rzeźba, czy też sztuka użytkowa (tkactwo artystyczne, ceramika, metaloplastyka) ${ }^{21}$.

Dla twórczości polskich artystek charakterystyczna była przewaga prac kameralnych (pod względem rozmiarów, ale i tematyki), chociaż zdarzały się

17 Zob. Muzeum Okręgowe im. Leona Wyczółkowskiego w Bydgoszczy (dalej: MOB), Biblioteka, Pierwsza wystawa artystek polskich, sygn. 32, Kartka pocztowa Wacława Widigiera z Warszawy, męża Wandy Gentil-Tippenhauer, do Muzeum Miejskiego z 24 XII 1929, b.p.

18 Zob. Przewodnik po wystawie Towarzystwa Zachęty Sztuk Pięknych, nr 51 (Warszawa: Towarzystwo Zachęty Sztuk Pięknych w Warszawie, luty 1930), 21; Teichert, „Wanda Anna Gentil-Tippenhauer," 161.

19 MOB, Biblioteka, XXIII Wystawy, Ausstellungen, sygn. 40, Wykaz prac Anieli Czarnowskiej, Wandy Gentil-Tippenhauer i Zofji Gerżabek-Małachowskiej oraz grafik z nowego zakupu, s. $1-3$.

20 Od 1904 r. kobietom zezwolono na studiowanie w Warszawskiej Szkole Sztuk Pięknych, a od 1920 r. mogły uczęszczać na zajęcia w krakowskiej Akademii Sztuk Pięknych, Maria Zientara, „Artystki polskie i ich sztuka w latach 1900-1939. Część I. Nurt narodowej sztuki dekoracyjnej," Krzysztofory. Zeszyty Naukowe Muzeum Historycznego Miasta Krakowa 25 (2007): 149-151.

${ }^{21}$ Anna Sieradzka, „Nie tylko Stryjeńska. Udział kobiet-artystek w tworzeniu stylu art déco w Polsce," w Kobieta i kultura. Kobiety wśród twórców kultury intelektualnej i artystycznej w dobie rozbiorów i w niepodległym państwie polskim, t. 4, red. Anna Żarnowska i Andrzej Szwarc (Warszawa: Wydawnictwo DiG, 1996), 204-210; Katarzyna Kulpińska, „Studentki szkół artystycznych i artystki w Polsce okresu międzywojennego - wybrane aspekty profesji," Acta Universitatis Lodziensis. Folia Sociologica 66 (2018): 33; por. Zientara, „Artystki polskie,” 152-170; Agnieszka Morawińska, „Malarki polskie między wojnami,” w Równe prawa i nierówne szanse. Kobiety w Polsce międzywojennej. Zbiór studiów, red. Anna Żarnowska i Andrzej Szwarc (Warszawa: Wydawnictwo DiG, 2000), 256. 
także dzieła monumentalne, realizowane na zlecenie władz państwowych lub Kościoła. Najczęściej kobiety na zamówienie malowały portrety i miniatury, wykonywały rzeźby niedużych rozmiarów, tkały: w ich dorobku artystycznym znajdujemy również kilimy, gobeliny, makaty ${ }^{22}$. Malarki, podobnie jak w XIX wieku, skupiały się na realizacji określonych, interesujących je, najczęściej neutralnych tematów, mimo że talent i umiejętności pozwalały im podjąć każdy motyw; na ich obrazach królowały zatem pejzaże, martwe natury, portrety oraz wątki rodzajowe. Posługiwały się olejem, akwarelą, pastelem, ołówkiem bądź węglem. Były obeznane z technikami i konwencjami charakterystycznymi dla wszystkich panujących w tym czasie kierunków sztuk plastycznych ${ }^{23}$ i należały do większości działających w Polsce grup artystycznych. Typowe było dla kobiet również to, że zajmowały się nie jedną wybraną, ale często dwiema, a nawet kilkoma dziedzinami sztuki. Okazję do prezentacji prac dawały im organizowane w kraju i za granicą liczne wystawy zbiorowe. Zdecydowanie rzadziej kobiety pokazywały swój dorobek na ekspozycjach indywidualnych ${ }^{24}$.

\section{„Ruda” Wanda - kim była?}

Wanda Gentil-Tippenhauer (1899-1965) urodziła się w Port-au-Prince na Haiti ${ }^{25}$, gdzie jej ojciec, Louis Wiepert Gentil-Tippenhauer, Niemiec, pracował od 1897 roku. Jako naukowiec i główny inżynier miejski prowadził on badania dotyczące wpływu warunków atmosferycznych na konstrukcje budowlane i odpowiadał za powstanie pierwszej kolei wąskotorowej na wyspie, był też autorem kilku prac naukowych ${ }^{26}$. Matka, Wiktoria, zajmowała się edukacją córek oraz pisała opowiadania i amatorsko malowała; to dzięki niej przyszła artystka - która według Wojciecha Szatkowskiego „wyrosła w atmosferze miłości ze strony rodziców i rodzeństwa, dobrobytu oraz dostępu

\footnotetext{
Kulpińska, „Studentki szkół artystycznych,” 47, 50; Zientara, „Artystki polskie,” 152.

Zientara, „Artystki polskie,” 152.

24 Kulpińska, „Studentki szkół artystycznych,” 48-50.

25 W. Gentil-Tippenhauer ur. 13 I 1899, zm. 12 VIII 1965 w Zakopanem, zob. Staniszewska, „Gentil-Tippenhauer Wanda Anna,” 304-305.

26 Wojciech Szatkowski, Józef Oppenheim, przyjaciel Tatr i ludzi (Zakopane-Łomianki: Muzeum Tatrzańskie / Wydawnictwo LTW, 2021), 296; Teichert, „Wanda Anna Gentil-Tippenhauer,” 161.
} 
do sztuki i kultury"27 - zainteresowała się malarstwem i zaczęła tworzyć wiersze $^{28}$. Wandę, ze względu na ognisty kolor włosów nazywaną „Rudą”, dla edukacji wysłano do Europy. Maturę uzyskała w Szkole Vinet w Lozannie ${ }^{29}$, artystycznie kształciła się na Państwowych Kursach dla Nauczycieli Rysunków przy Szkole Sztuk Pięknych w Warszawie, ukończyła także hamburską Kunstgewerbeschule ${ }^{30}$.

Malarka wiele podróżowała zarówno po krajach europejskich, jak i po Stanach Zjednoczonych. Była członkinią Polskiego Towarzystwa Artystycznego, Związku Polskich Artystów Plastyków i Towarzystwa Zachęty Sztuk Pięknych w Warszawie oraz Podhalańskiego Związku Plastyków w Zakopanem $^{31}$. Jej prace pokazywano na licznych wystawach zbiorowych oraz indywidualnych, zarówno krajowych, jak i zagranicznych. W latach 1929, 1935 i 1938 swój dorobek artystyczny zaprezentowała na ekspozycjach organizowanych przez Towarzystwo Zachęty Sztuk Pięknych w Warszawie ${ }^{32}$. W latach trzydziestych XX stulecia cykl jej pejzaży zakopiańskich wystawiono w stołecznym Domu Handlowym B-ci Jabłkowskich i w Salonie ZPAP w Instytucie Propagandy Sztuki. Intensywny rozwój twórczy Gentil-Tippenhauer zaowocował także udziałem w wystawie w Zakopanem w 1935 roku. Z pokazów zagranicznych jej prac można wymienić wystawy w Lyonie, Mediolanie, Turynie ${ }^{33}$.

„Ruda” Wanda posługiwała się głównie akwarelą i temperą. W tematyce jej dzieł przeważały pejzaże, ale pojawiały się również sceny rodzajowe, motywy religijne i rośliny (kwiaty). Od połowy lat dwudziestych XX stulecia inspirowały ją Tatry i jazda na nartach, toteż na jej obrazach najczęściej

27 Cyt. za: Szatkowski, „Józef Oppenheim,” 297.

28 W Muzeum Tatrzańskim w Zakopanem znajdują się zeszyty z poezją Wandy Gentil-Tippenhauer. Z 1913 r. pochodzi wiersz „O nic Cię więcej Boże mój nie proszę”, zob. Szatkowski, „Józef Oppenheim,” 296-298.

29 Teichert, „Wanda Anna Gentil-Tippenhauer,” 161; S.P.O. [Stefania Podhorska-Okołów], „Malarstwo Wandy Gentil-Tippenhauer,” Bluszcz. Społeczno-Literacki Tygodnik Kobiecy, 10 grudnia 1938, 2 (1246).

30 Staniszewska, „Gentil-Tippenhauer Wanda Anna,” 304.

31 Staniszewska, „Gentil-Tippenhauer Wanda Anna,” 304; Teichert, „Wanda Anna Gentil-Tippenhauer,” 161; Wojciech Szatkowski, „'Ruda' Wanda - z Haiti do Zakopanego,” http://muzeumtatrzanskie.pl/ruda-wanda-z-haiti-do-zakopanego/, dostęp 16 lipca 2020.

32 Staniszewska, „Gentil-Tippenhauer Wanda Anna,” 304.

33 Staniszewska, „Gentil-Tippenhauer Wanda Anna,” 304; S.P.O., „Malarstwo,” 2 (1246); Szatkowski, „Józef Oppenheim,” 299. 
można było zobaczyć polskie góry ${ }^{34}$; tę część malarstwa Gentil-Tippenhauer scharakteryzowano w 1938 roku na łamach tygodnika „Bluszcz”: „Wyobraźnia artystki przetwarza znane zarysy grzbietów skalnych i turni, idealizuje ich koloryt, daje niejako syntezę swojej indywidualnej wizji Tatr za pomocą środków technicznych całkowicie opanowanych. Jej faktura akwarelowa ma dużo lekkości z jednoczesną pewnością ręki. Można się nie zgodzić z fantastyczną interpretacją artystki, ale trudno nie przyznać jej motywom wartości dekoracyjnych. Są między jej kompozycjami sceny z życia górali z drobiazgowo wykończonymi figurkami ludzkimi, tworzącymi jakby jakąś jasełkową scenerię na tle krajobrazu górskiego" ${ }^{35}$. Wśród podejmowanych przez malarkę motywów nie zabrakło także widoków Bydgoszczy i innych miejscowości. Oprócz sztalugowego Gentil-Tippenhauer uprawiała też malarstwo ścienne i potrafiła malować na szkle. W kościele pw. św. Katarzyny w Zgierzu znajdują się zaprojektowane przez artystkę ekspresyjne witraże przedstawiające Chrystusa ukrzyżowanego, Matkę Bożą wśród kwiatów oraz kilku świętych, w tym św. Jadwigę, św. Kazimierza, św. Joannę d’Arc oraz św. Tadeusza. Wanda nie stroniła przy tym od architektury wnętrz, a nawet konserwacji dzieł sztuki ${ }^{36}$. Zajmowała się także batikiem. W 1927 roku w warszawskim Towarzystwie Zachęty Sztuk Pięknych została wyróżniona za batikowy Szal zielony ${ }^{37}$. Wymagającą cierpliwości i dużej precyzji techniką „barwienia z zastosowaniem masy z płynnego wosku" malarka zainteresowała się najprawdopodobniej w Zakopanem, może w Warszawie; w latach dwudziestych XX stulecia w stolicy Tatr działały warsztaty batikarskie, których tradycje Gentil-Tippenhauer przejęła i kontynuowała również po drugiej wojnie światowej ${ }^{38}$. Dodatkowo projektowała kilimy, które m.in. w 1923 roku wystawiło Towarzystwo Sztuk Pięknych w Warszawie. Opisano je wówczas w „Kurierze Warszawskim”: „widzimy szeregi kilimów jej pomysłu, przyznajemy, doskonałych - rzadko kiedy spotykaliśmy taką doskonałą całość i taką beztroską formę; jest to śmiałe wyłamanie się z schematu, zabijającego polskie kilimy doby ostatniej. W tych

34 Staniszewska, „Gentil-Tippenhauer Wanda Anna,” 304; por. Szatkowski, „Józef Oppenheim,” 343-344.

35 S.P.O., „Malarstwo,” 2 (1246).

36 Teichert, „Wanda Anna Gentil-Tippenhauer,” 161; Staniszewska, „Gentil-Tippenhauer Wanda Anna," 304-305.

37 Staniszewska, „Gentil-Tippenhauer Wanda Anna,” 304.

38 Szerzej Joanna Radziewicz, „Batik - z Indonezji do Polski,” https://rme.cbr.net.pl/index. php/archiwum-rme/739-listopad-grudzien-nr-82/kultura-i-tradycje-ludowe/1102-batik-z-indonezji-do-polski, dostęp 7 września 2021. 
ściennych dywanach można naprawdę zagustować; trzeba, aby z pomiędzy tych prac wybrano najlepsze okazy i przesłano je na wystawę sztuki dekoracyjnej do Paryża. Zasługują na to" ${ }^{39}$. W 1931 roku ukazała się książka Wiktorii Gentil-Tippenhauer pt. Bajki murzyńskie z Haiti, którą Wanda zilustrowała ${ }^{40}$ (il. 3), z pewnością inspirując się wspomnieniami o ludziach z tropikalnej wyspy poznanych w latach szczęśliwego dzieciństwa; sposób przedstawienia życia codziennego mieszkańców Haiti ujawnia dobrą znajomość tematu. Niestety, większość przedwojennego dorobku twórczego artystki nie przetrwała Powstania Warszawskiego ${ }^{41}$.

Jeszcze przed wojną Gentil-Tippenhauer związała się z Józefem Oppenheimem, taternikiem, ratownikiem górskim, kierownikiem Tatrzańskiego Ochotniczego Pogotowia Ratunkowego oraz fotografem i autorem wielu książek. Od około 1925 roku przyjeżdżała do Zakopanego, gdzie razem odbywali wycieczki górskie, zwłaszcza w wiosennej aurze. Z „Opciem”, jak go wszyscy nazywali, łączyła artystkę wyjątkowa relacja, oparta na przyjaźni i zauroczeniu... „może czymś więcej” ${ }^{2}$. Co ciekawe, biografista „znawcy Tatr” Wojciech Szatkowski w archiwaliach Instytutu Pamięci Narodowej odnalazł

39 „Bydgoszcz w Zachęcie Warszawskiej,” Gazeta Bydgoska, 2 października 1923, 4 (przedruk z Kuriera Warszawskiego).

40 Wiktoria Gentil-Tippenhauerowa, Bajki murzyńskie z Haiti (Warszawa: Polska Zjednoczona, 1931); por. Staniszewska, „Gentil-Tippenhauer Wanda Anna,” 304; Szatkowski, „Józef Oppenheim," 299.

41 Staniszewska, „Gentil-Tippenhauer Wanda Anna,” 304, podaje, że cały międzywojenny dorobek artystyczny Gentil-Tippenhauer uległ zniszczeniu; por. Teichert, „Wanda Anna Gentil-Tippenhauer," 161.

42 List W. Gentil-Tippenhauer do J. Oppenheima z 19 I 1937 r. także nie określa jednoznacznie ich relacji: „Mijają lata, a ja do niczego dojść nie mogę. Szmelc mój drogi panie. Na chłopów patrzeć nie mogę. Też stek łgarzy! Odkąd się narodziłam, słyszę, jak mężczyźni publicznie ironizują na temat kobiet i za psi pazur je mają w rozmowach towarzyskich. Tymczasem, odkąd stałam się kobietą, zaledwie drzwi się zamkną i zostanie chłop sam na sam ze mną, każdy z miejsca się zmienia i łasi się o przereklamowaną przyjemność. Kiedyż więc ci szlachetni panowie nie kłamią, powiedz mi. Widzę, że i Tobie jakoś spieszno do przereklamowanej przyjemności, skoro się tak miły dopominasz o mój przyjazd. Czyżby dziewczynek zabrakło w Zakopanem, a Turbacz na pięcie się wykręcił? Czy chcesz zatuszować zbyt wiele poczynionych eskapad? Zawiedziesz się mój drogi - jestem do lampy, głowa mnie ciągle boli, straciłam przekonanie do chłopów. Każdy zapowiada dziesięć razy, a jak co do czego przyjdzie - po razie śpi jak zabity, a po dwóch puszy się jak bohater. A często kobieta nawet nie poczuje tak to krótko trwa! [...]. Do niczego Cię nie zobowiązuję, jesteś absolutnie wolny, przeszłość wykreślona, ale jedynie do chwili, dokąd Ci się nie zachce przereklamowanej przyjemności... Więc miej się na baczności, czy warto wiele cholery doruszać...”, cyt. za: Szatkowski, „Józef Oppenheim,” 342-343; Wojciech Szatkowski, „'Ruda’ Wanda i ‘Opcio.' Love story z Pysznej?,” http://archiwalna.muzeumtatrzanskie.pl/UserFiles/File/ PDF/Ruda_Wanda_i_Opcio_Love_story_z_Pysznej.pdf, dostęp 28 sierpnia 2021; Klaudia Król, 
dokument, w którym Wanda określona została jako „żona Oppenheima”43. Malarka wzbogaciła swoimi rysunkami (schematami sytuacyjnymi) napisany przez Oppenheima przewodnik narciarski pt. Szlaki narciarskie Tatr Polskich i główne przejścia na południową stronę (1936) ${ }^{44}$.

Na łamach międzywojennej prasy artystka recenzowała wystawy i pisała krytyczne artykuły o sztuce, m.in. w „Kurierze Łódzkim” i w wileńskim „Przeglądzie Artystycznym” ${ }^{45}$. W 1926 roku w „Gazecie Bydgoskiej” ukazał się jej tekst o polichromii, którą w kościele w Szaradowie wykonał prof. Bronisław Bartel $^{46}$.

Na początku drugiej wojny światowej Gentil-Tippenhauer wraz z „Opciem” przebywała na Wołyniu, gdzie pracowała w fabryce wyrobów drzewnych. Od 1942 roku w Warszawie uczyła rysunku na tajnych kompletach i ukrywała Oppenheima, który z powodu żydowskiego pochodzenia był zagrożony aresztowaniem i śmiercią ${ }^{47}$. W czasie Powstania Warszawskiego taternik został sanitariuszem i pomagał rannym mieszkańcom. Po ucieczce ze zrujnowanego miasta Wanda przebywała w Pruszkowie. W końcu marca 1945 roku zamieszkała z Oppenheimem i matką w Zakopanem ${ }^{48}$. W styczniu 1946 roku Józef Oppenheim został zamordowany przez bandytów w ich wspólnym domu na Krzeptówkach, a malarka - postrzelona w głowę ${ }^{49}$; po tym wydarzeniu na dwa lata wyjechała do Warszawy ${ }^{50}$ (il. 4).

Po powrocie na Podhale Gentil-Tippenhauer zamieszkała wraz z przyjaciółkami na Uboczu (wynajmowała pokój) i przez resztę życia prowadziła szeroką działalność artystyczno-kulturalną, m.in. organizowała wystawy i brała udział w pokazach ZPAP (którego była członkinią). W 1961 roku została zorganizowana wystawa indywidualna jej prac ${ }^{51}$. Jednocześnie artystka wzięła pod opiekę twórców ludowych, pisała krytyczne teksty w „Polskiej Sztuce

„Zakopiańskie love story. Portal Tatrzański,” https://portaltatrzanski.pl/wiedza/historia/zakopianskie-love-story,1651, dostęp 29 listopada 2020.

Szatkowski, „Józef Oppenheim,” 292, 341.

44 Zob. Józef Oppenheim, Szlaki narciarskie Tatr Polskich i główne przejścia na południową stronę (Kraków: Polski Związek Narciarski, 1936).

45 Teichert, „Wanda Anna Gentil-Tippenhauer,” 161.

46 Wanda Gentil-Tippenhauer, „Kościół w Szaradowie,” Gazeta Bydgoska, 12 września 1926, 6.

47 Szatkowski, „Józef Oppenheim,” 354-358.

48 Szatkowski, „Józef Oppenheim,” 359; Staniszewska, „Gentil-Tippenhauer Wanda Anna,” 304.

49 Szerzej Szatkowski, „Józef Oppenheim,” 8-9, 385-412.

50 Szatkowski, „Józef Oppenheim,” 414; Król, „Zakopiańskie love story.”

51 Staniszewska, „Gentil-Tippenhauer Wanda Anna,” 304; Szatkowski, „Józef Oppenheim,” 424-426. 
Ludowej” i „Wierchach” oraz książki o turystyce i narciarstwie, przygotowała maszynopis książki SOS $w$ Tatrach ${ }^{52}$. Wcześniej, tuż po śmierci Oppenheima, opublikowała w „Wierchach” ich wspólne wspomnienia pt. Pamięci umarłych schronisk (1948) ${ }^{53}$. W 1961 roku ukazało się pierwsze wydanie $W$ stronę Pysznej ${ }^{54}$ - książki, którą Wanda Gentil-Tippenhauer napisała wraz ze Stanisławem Zielińskim i która do dzisiaj jest obowiązkową lekturą wszystkich miłośników Tatr. Ta przepiękna opowieść o górach i ludziach w nich zakochanych została oparta na wspomnieniach „Opcia” 55 - wielokrotnego uczestnika wypraw ratunkowych i duszy towarzystwa ${ }^{56}$, ale także na szczegółowych relacjach Wandy ${ }^{57}$. Jak dowodzi Wojciech Szatkowski, głównie dzięki niej przetrwała pamięć o znakomitym taterniku, nietuzinkowym, wyrazistym człowieku z Zakopanego ${ }^{58}$.

Jako malarka i miłośniczka gór Gentil-Tippenhauer była w stolicy Tatr osobą znaną i powszechnie lubianą - „zakopiańskim kolorowym ptakiem”59. Wędrowała po górach, jeździła na nartach i pasjonowała się sztuką ludową Podhala. Razem z Oppenheimem, do którego zwracała się w kilku listach „Drogi, kochany Józiu”, ,Najdroższy Józiu”, „Miły Józiu”, tworzyli bardzo oryginalną parę o zbieżnych temperamentach i pasjach ${ }^{60}$.

Wanda Gentil-Tippenhauer zmarła po ciężkiej chorobie nowotworowej i spoczęła na Cmentarzu Zasłużonych na Pęksowym Brzyzku w Zakopanem. Grób malarki zdobi drewniany pomnik w formie góralskiego tryptyku z sercem, wykonany przez uczniów Antoniego Rząsy, zakopiańskiego rzeźbiarza i pedagoga ${ }^{61}$.

52 Zachowały się niepublikowane teksty Gentil-Tippenhauer: „Józef Oppenheim”, „Memorandum” i „Pamięci Józefa Oppenheima”, zob. Szatkowski, „Józef Oppenheim,” 462.

53 Szatkowski, „'Ruda' Wanda - z Haiti.”

54 Książka doczekała się pięciu wydań (ostatnie w 2008 r.), lecz tylko pierwsze wyszło jako dzieło dwojga autorów; po śmierci artystki Zieliński podawał wyłącznie swoje nazwisko i kreował się na jedynego autora publikacji. Książka, co trzeba wyraźnie zaznaczyć, powstała z inicjatywy Wandy, a także dzięki jej wspomnieniom i materiałom, szerzej zob. Szatkowski, „Józef Oppenheim,” 417-423.

55 Staniszewska, „Gentil-Tippenhauer Wanda Anna,” 305.

56 Król, „Zakopiańskie love story.”

57 Szatkowski, „'Ruda' Wanda i 'Opcio'.”

58 Szatkowski, „Józef Oppenheim,” 414-423.

59 Cyt. za: Szatkowski, „Józef Oppenheim,” 428.

60 Szatkowski, „Józef Oppenheim,” 342; Szatkowski, „Ruda’ Wanda i 'Opcio’” Szatkowski, „Ruda' Wanda - z Haiti,” zob. też Teichert, „Wanda Anna Gentil-Tippenhauer,” 161; Staniszewska, „Gentil-Tippenhauer Wanda Anna,” 305.

61 Szatkowski, „Józef Oppenheim,” 429; Szatkowski, „'Ruda’ Wanda i ‘Opcio’.” 


\section{Dzieła Gentil-Tippenhauer na wystawach bydgoskiego Muzeum Miejskiego}

W sierpniu 1923 roku powołano do życia bydgoskie Muzeum Miejskie. Placówka przejęła zbiory zgromadzone przez Niemców w czasach pruskich i rozpoczęła sukcesywny rozwój zarówno na polu pozyskiwania nowych obiektów, jak i w zakresie działalności wystawienniczej. Do 1939 roku instytucja zorganizowała wiele różnorodnych ekspozycji, z których najliczniejsze miały profil artystyczny. Brali w nich udział nie tylko lokalni twórcy, ale także artyści z całej Polski. Z placówką współpracowało wiele stowarzyszeń kulturalnych i grup plastycznych. Obok teatru i biblioteki, Muzeum Miejskie miało największy wkład w realizację misji kulturotwórczej w międzywojennej Bydgoszczy ${ }^{62}$. Malarką, którą bydgoska placówka muzealna często zapraszała do zaprezentowania swojej twórczości, była Wanda Gentil-Tippenhauer.

W grudniu 1927 roku otwarto wystawę „Malarstwo Kazimierza Stabrowskiego i Wandy Gentil-Tippenhauer”63 (il. 5). Muzeum Miejskie pokazało wówczas siedemdziesiąt prac plastycznych ${ }^{64}$, wśród których było kilkanaście obrazów oraz batikowych szali i makat malarki. Najbardziej interesujące wydają się jej dzieła o tematyce bydgoskiej, czyli Kanał w Bydgoszczy (1925), Domy w Bydgoszczy i Pod Bydgoszczq oraz tkaniny. W wykazie prac figurują także jej obrazy o motywach włoskich i małopolskich oraz projekty polichromii ${ }^{5}$.

62 Hojka, Muzeum w Bydgoszczy, 14-25.

63 Ekspozycja „Malarstwo Kazimierza Stabrowskiego i Wandy Gentil-Tippenhauer” trwała od 11 XII 1927 do 22 I 1928 r., zob. MOB, Biblioteka, Wykaz teczek z wystawami, [s.] 4; MOB, Biblioteka, Działalność Muzeum 1923-1945 (pisma różne), Wystawy - Muzeum Miejskie, b.p.; Hojka, Muzeum w Bydgoszczy, 77.

64 „Z Muzeum Miejskiego,” Dziennik Bydgoski, 13 grudnia 1927, 8.

65 MOB, Biblioteka, Malarstwo Kazimierza Stabrowskiego, Wandy Gentil-Tippenhauer, 11 XII 1927-10 I 1928, sygn. 19, Pismo do Muzeum Miejskiego i spis obrazów Wandy Gentil-Tippenhauer z 1 XII 1927 r., [s.] 156-157; prezentowane obrazy: Świątynia Antonjusza (Rzym), Santa Maria l'antiqua na Forum, Cyrk Maksenjusza (Palatyn), Ogrody w Tivoli, Skały na Capri, Cyprysy pod Florencją, Wenecja, Giardino del Lago (Rzym), Wejście do pałacu cezarów, Wieś w Małopolsce Wschodniej, Stratyń (Małopolska Wschodnia), Folwark (Małopolska Wschodnia), Baszta (Małopolska Wschodnia), Baszta (Małopolska Wschodnia), Róże (Małopolska Wschodnia), Kanał w Bydgoszczy, Domy w Bydgoszczy, Pod Bydgoszcza, Projekty polichromji w kościele św. Katarzyny w Zgierzu, Szkic do polichromji kaplicy w pałacu hr. Krasickich, Projekty polichromji, Wniebowzięcie, inne obiekty: szale, makaty batikowe, zob. Katalog jubileuszowej wystawy zbiorowej obrazów prof. Kazimierza Stabrowskiego w 40-lecie jego pracy artystycznej oraz p. Wandy Gentil-Tippenhauer grudzień 1927 (Bydgoszcz: Muzeum Miejskie w Bydgoszczy, 1927), b.p. 
Obraz Kanał w Bydgoszczy (il. 6) przedstawia motyw pejzażowy: biały budynek z czerwonym spadzistym dachem i szarymi szkarpami, ustawiony blisko tafli wody, wśród drzew. Drzewa i krzewy są malowane szerokimi plamami w tonacji ugrowo-zielonej, odbicie roślinności i budynku w lustrze wody potraktowane zostało szkicowo. Szczyt budynku z prawej strony częściowo zakrywają gałęzie ${ }^{66}$. Dom usytuowany jest ukośnie do linii brzegowej wody - „kanału” na Wyspie Młyńskiej (najpewniej przy ul. Mennica 6 - dzisiaj Centrum Edukacji Muzealnej, oddział bydgoskiego Muzeum Okręgowego im. Leona Wyczółkowskiego ${ }^{67}$. W kilku miejscach, szczególnie w partii nieba, widoczny jest oryginalny kolor papieru. Kompozycja obrazu jest zrównoważona, zbudowana według osi pionowej, z mocno zaznaczoną ciemną kreską linią brzegową. W prawym dolnym rogu znajduje się sygnatura artystki: Wanda Gentil-Tippenhauer ${ }^{68}$. Prezentowana na wystawie jedwabna chusta, wykonana przed rokiem 1927, jest półkoliście wycięta u dołu i ozdobiona frędzlami. Asymetrycznie ustawione elementy kompozycji mają charakter dekoracyjny, umieszczone na jasnym tle postacie ludzkie stylizowane są na greckie malarstwo wazowe i egipskie freski. Scena w centralnej części chusty przedstawia ukwiecone drzewo i pod nim siedzące na krzesłach dwie postaci wachlowane przez stojącą służącą; po obu stronach drzewa towarzyszą im grający na harfach, a przy wachlowanej postaci z lewej strony klęczy kobieta. Za harfiarzami płyną dwie długie łodzie; oprócz sterników są tam grajkowie zajęci grą na instrumentach muzycznych i żonglerzy, którzy zabawiają postaci odpoczywające pod koroną drzewa. W rogach tkaniny autorka zaprojektowała dwa stylizowane pawie trzymające w szponach kwiaty. Całość kompozycji zamknięta jest ozdobną bordiurą $\mathrm{w}$ formie plecionki. Zdobiące dodatkowo tkaninę długie, cienkie frędzle wykonane są z nici barwionych w gamie brązowo-szarej, chusta zaś jest w kolorach kremowym, szaro-zielonym i lekko różowym. W lewym górnym rogu znajduje się sygnatura: WANDA GENTIL-TIPPENHAUER ${ }^{69}$ (il. 7).

66 W karcie naukowej widnieje błędny tytuł obrazu, zob. MOB, Dział Sztuki, Nad kanałem, Wanda Gentil-Tippenhauer, nr inw. MOB MW-413, karta naukowa zabytku, oprac. Elżbieta Kantorek, Bydgoszcz 1978. Opis obrazu konsultowany z historykiem sztuki, dr Moniką Kosteczko-Grajek z Bydgoszczy.

67 Konsultacja archeologa dr. Wojciecha Siwiaka z Bydgoszczy: brany jest pod uwagę także obiekt przy ul. Mennica 4.

68 Opis obrazu konsultowany z historykiem sztuki, dr Moniką Kosteczko-Grajek z Bydgoszczy.

69 MOB, Dział Historii, Chusta, Wanda Gentil-Tippenhauer, nr inw. MOB H-917, karta naukowa zabytku, oprac. Danuta Sójkowska, Bydgoszcz 2017. Opis zabytku konsultowany z historykiem sztuki dr Moniką Kosteczko-Grajek z Bydgoszczy. 
Bydgoskiej publiczności akwarela Kanał w Bydgoszczy została ponownie zaprezentowana na ekspozycji obiektów ze zbiorów Muzeum Miejskiego, którą traktowano jako wystawę stałą. Nosiła ona tytuł „Galeria Miejska obrazów i rzeźb w Bydgoszczy”, a otwarto ją w czerwcu 1929 roku ${ }^{70}$. Obraz Gentil-Tippenhauer, nabyty przez placówkę w 1928 roku, wystawiono w towarzystwie ponad dwustu dwudziestu muzealiów, pochodzących głównie z zakupów. Wśród tych dzieł sztuki można wymienić prace polskich malarek Anny Bilińskiej-Bohdanowiczowej i Olgi Boznańskiej ${ }^{71}$.

Niezwykle ciekawą ekspozycją, na której pokazano także prace Wandy Gentil-Tippenhauer, była zainaugurowana w styczniu 1930 roku „Pierwsza wystawa artystek polskich” (il. 8). Zaproszono wtedy głównie twórczynie, które rok wcześniej wzięły udział w „Powszechnej wystawie krajowej” w Poznaniu - dla Gentil-Tippenhauer zrobiono wyjątek ${ }^{72}$. Dorobek zarówno autorki Kanału w Bydgoszczy, jak i pozostałych artystek cieszył się już wówczas uznaniem w Polsce ${ }^{73}$. Była to pierwsza, pionierska w mieście nad Brdą, ale i w zachodniej części kraju wystawa dzieł dwudziestu polskich artystek z Warszawy, Poznania, Krakowa, Lwowa i Wilna. Z całą pewnością miała ona prestiżowy charakter ${ }^{74}$.

70 Wystawa otwarta była od 23 VI do 6 X 1929 r., Hojka, Muzeum w Bydgoszczy, 23, 77.

71 Katalog Galerji Miejskiej, wystawa czerwiec-wrzesień 1929 (Bydgoszcz: Muzeum Miejskie w Bydgoszczy, 1929), 7; Katalog ilustrowany Miejskiej Galerji obrazów i rzeźb w Bydgoszczy (Bydgoszcz: Muzeum Miejskie, 1929), b.p.

72 Wystawa udostępniona była od 26 I do 9 III 1930 r., MOB, Biblioteka, Pierwsza wystawa artystek polskich, sygn. 32, Wystawa artystek polskich (malarstwo i rzeźba), b.p, Zaproszenie na otwarcie I. Wystawy Artystek Polskich styczeń 1930 r., b.p., Wystawa artystek polskich, 1930, b.p.; „Kronika. Wystawa artystek polskich”, Dziennik Bydgoski, 26 stycznia 1930, 12; „Wystawa Artystek Polskich," Gazeta Bydgoska. Kurjer Bydgoski, 26 stycznia 1930, 6; Hojka, Muzeum w Bydgoszczy, 77; Dział Sztuki: Powszechna Wystawa Krajowa (Poznań: Powszechna Wystawa Krajowa 1929), 10-11, 14, 16-17, 20-21; zob. też Agata Jakubowska, „Historia wystaw sztuki kobiet w Polsce. Wstęp,” Sztuka i Dokumentacja 15 (2016): 7; „Wystawa: I Wystawa Artystek Polskich, Wystawy Sztuki Kobiet”, http://wystawykobiet.amu.edu.pl/wystawa/i-wystawa-artystek-polskich,33.html, dostęp 16 czerwca 2018.

73 „Kronika. Wystawa artystek,” 12.

74 Autorkami dzieł pokazanych na wystawie, oprócz Gentil-Tippenhauer, były: Zofia Albinowska-Minkiewiczowa, Aneri (Irena Weissowa), Anna Berent, Stanisława Centnerszwer, Alina Czarnowska, Janina Konarska, Olga Niewska, Kazimiera Pajzderska, Jadwiga Tetmajer-Naimska, Michalina Krzyżanowska, Ludmiła Kusztelanówna, Malwina Menes-Kuczyńska, Janina Gessnerówna, Zofia Dziurzyńska-Rosińska, Dora Mukułowska, Olga Neymanowa, Leona Szczepanowicz, Anna Wilczyńska i Maria Wodzicka, „Kronika. Wystawa artystek,” 12; Katalog I Wystawy Artystek Polskich styczeń-luty 1930 (Bydgoszcz: Muzeum Miejskie w Bydgoszczy, 1930), 1-3; MOB, Biblioteka, Pierwsza wystawa artystek polskich, sygn. 32, Wystawa artystek polskich z 1930 r., b.p.; Zgłoszenia na wystawę artystek polskich w Muzeum Miejskim 
Otwarcie wystawy nastąpiło w obecności decernenta Muzeum Miejskiego, inż. Tadeusza Janickiego oraz trzech artystek, w tym Wandy Gentil-Tippenhauer. Lokalna prasa donosiła: „Dość licznie przybyła [...] publiczność”, która „z zadowoleniem oglądała wystawione prace rzeźbiarskie i malarskie, przed całym szeregiem prac, prowadząc żywą dyskusję - co świadczy, że nie brak na wystawie dzieł, istotnie interesujących" ${ }^{\text {" }}$. Zygmunt Malewski na łamach „Dziennika Bydgoskiego” tak skomentował ekspozycję sztuki kobiet w mieście nad Brdą: „Kobieta z pędzlem czy z dłótem [sic] w ręku - to zawsze widok niezwykły, drażniący ciekawość, emocjonujący i frapujący. Ale cała osobna wystawa obrazów i rzeźb, których twórczyniami są wyłącznie artystki - to rzecz już więcej niż niezwykła, to żeńska Olimpiada, kobiecy wyścig, pocichu [sic], na lekkich stopach, pośród laurowych szelestów, pod deszczem róż, tęczowych kolorów i blasków, w obecności tysięcy wpatrzonych oczu, pulsujących skroni, bijących serc... Kobiecy bieg do mety!... Bieg artystyczny" ${ }^{76}$. Wanda Gentil-Tippenhauer, która przywiozła swoje prace do Bydgoszczy już na początku stycznia ${ }^{77}$, zaproponowała bydgoskim miłośnikom sztuki różnorodne pejzaże, wśród nich szczególnie wyróżniał się obraz Giewont ${ }^{78}$.

Do udziału w kolejnym pokazie Muzeum Miejskie zaprosiło trzy artystki związane z miastem nad Brdą, zamierzając przy okazji pochwalić się pracami graficznymi świeżo zakupionymi do zbiorów muzealnych. „Wystawę obrazów i grafiki artystek-malarek pp. A. Czarnowskiej, W. Gentil-Tippenhauer i Z. Gerżabek-Małachowskiej oraz grafiki z nowego zakupu"79 (il. 9) otwarto

1929/1930, b.p.; por. Joanna Sosnowska, Poza kanonem. Sztuka polskich artystek 1880-1939 (Warszawa: Instytut Sztuki PAN, 2003), 231; MOB, Biblioteka, Pierwsza wystawa artystek polskich, sygn. 32, Informacja Muzeum Miejskiego do lokalnej prasy o otwarciu wystawy z dn. 23 I 1930 r., b.p., Komunikat. Przedłużenie wystawy artystek polskich, 4 II 1930, b.p.

75 „Wystawa malarek i rzeźbiarek,” Gazeta Bydgoska. Kurjer Bydgoski, 28 stycznia 1930, 5.

76 Z. M. [Zygmunt Malewski], „Wystawa artystek polskich,” Dziennik Bydgoski, 4 lutego 1930, 5 (zachowano oryginalną pisownię).

77 MOB, Biblioteka, Pierwsza wystawa artystek polskich, sygn. 32, Kartka pocztowa Wacława Widigiera z Warszawy, męża Wandy Gentil-Tippenhauer, do Muzeum Miejskiego z 24 XII 1929, b.k.

78 Prezentowane akwarele: Nad rzeka, Polski brzeg, Wenecja, Giewont i Frascati, zob. Katalog I Wystawy Artystek Polskich, 1-3.

79 Wystawę prezentowano od 20 III do 10 IV 1932 r., Hojka, Muzeum w Bydgoszczy, 78; MOB, Biblioteka, Wykaz teczek z wystawami, 7; MOB, Biblioteka, Wystawa obrazów i grafiki artystek-malarek zamieszkałych w Bydgoszczy oraz grafiki zakupionej w ostatnim roku do zbiorów muzeum, 20 III-10 IV 1932, sygn. 45, Zaproszenie na otwarcie wystawy obrazów i grafiki artystek-malarek pp. A. Czarnowskiej, W. Gentil-Tippenhauer i Z. Gerżabek-Małachowskiej oraz grafiki z nowego zakupu, marzec 1932, b.p.; „Z Muzeum Miejskiego,” Dziennik Bydgoski, 9 kwietnia 1932, 10. 
w marcu 1932 roku. W lokalnej prasie odnotowano, że Wanda Gentil-Tippenhauer zaprezentowała „30 akwarel z Tatr i z Bydgoszczy. [...], a przez sale Muzeum przesunęło się kilkadziesiąt osób, z zainteresowaniem oglądających tę nową ekspozycję i żywo dyskutujących na temat jej wartości”" ${ }^{80}$. Wzrok odbiorców przykuwały szczególnie akwarele przedstawiające motywy bydgoskie. Mieszkańców miasta urzekły pejzaże z widokiem na rzekę Brdę, Kanał Bydgoski, śluzę i Wenecję bydgoską (pokazaną aż w siedmiu odsłonach). Równie ciekawe były obrazy prezentujące spichrze i kościół farny - malarka uwieczniła najpiękniejsze miejsca i architekturę Bydgoszczy. Miasto nad Brdą ewidentnie ją fascynowało i inspirowało, pobudzało wyobraźnię, a wybór akwarel o tematyce bydgoskiej, jakiego dokonała, był z pewnością przemyślany i niewątpliwie trafny. Na wystawie w Muzeum Miejskim artystka pokazała również prace poświęcone polskim górom, m.in. Giewont, Dolinę Pięciu Stawów i Dolinę Białego oraz widoki pobliskiego Grudziądza ${ }^{81}$.

Wanda Gentil-Tippenhauer ostatni raz przedstawiła w Bydgoszczy swoje prace w połowie grudnia 1934 roku. Na „Dorocznej wystawie grupy plastyków pomorskich” („VI Wystawie grupy plastyków pomorskich”; il. 10) swoją twórczość prezentowało lokalne środowisko artystyczne ${ }^{82}$. Malarka nie

80 „Otwarcie nowej wystawy w Muzeum Miejskim”, Gazeta Bydgoska, 22 marca 1932, 7; MOB, Biblioteka, Wystawa obrazów i grafiki artystek-malarek zamieszkałych w Bydgoszczy oraz grafiki zakupionej w ostatnim roku do zbiorów muzeum, 20 III-10 IV 1932, sygn. 45, Informacja do lokalnej prasy Muzeum Miejskiego o wystawie z dn. 30 marca 1932 r., b.p.

81 Prezentowane akwarele: Bydgoszcz - Spichrze, Bydgoszcz - Brda, Bydgoszcz - Śluza, Bydgoszcz - Śluza, Bydgoszcz - Nad Kanałem, Bydgoszcz - Fara, Grudziądz - Spichrze, Grudziądz Spichrze, Grudziądz - Trynka, Mnich, Krokusy, Krokusy, Żabie wierchy, Dolina 5 Stawów, Schronisko w 5 Stawach, Listonosz, Bydgoszcz - Wenecja bydgoska I, Bydgoszcz - Wenecja bydgoska II, Bydgoszcz - Wenecja bydgoska III, Bydgoszcz - Wenecja bydgoska IV, Bydgoszcz - Wenecja bydgoska V, Bydgoszcz - Wenecja bydgoska VI, Bydgoszcz - Wenecja bydgoska VII, Bydgoszcz - Brda, Giewont, Chałupy góralskie, Cyrla, Kominy tylkowe, Widok z Zakopanego, Dolina Białego, zob. MOB, Biblioteka, XXIII Wystawy, Ausstellungen, sygn. 40, Wykaz prac Anieli Czarnowskiej, Wandy Gentil-Tippenhauer i Zofji Gerżabek-Małachowskiej oraz grafik z nowego zakupu, 1-4.

82 Wystawę otwarto 16 XII 1934 i trwała do 20 I 1935 r., Hojka, Muzeum w Bydgoszczy, 78; (hak) [Henryk Kuminek], „Wystawa Plastyków Pomorskich dowodem żywotności kulturalnej regjonu,” Dziennik Bydgoski, 19 grudnia 1934, 8; Marta Borowska, „Wystawy Związku Plastyków Pomorskich i Grupy Plastyków Pomorskich w Muzeum Miejskim w Bydgoszczy w latach 1930-1936,” Porta Aurea 17 (2018): 151; zob. też Barbara Chojnacka, „Od bydgoskiej 'Zachęty’ do 'Salonów Bydgoskich.' Związki i grupy artystyczne w latach 1921-1939,” w 100 lat Związku Polskich Artystów Plastyków. Zaczęło się w Krakowie w roku 1911. Historia ZPAP 1911-1939 w oparciu o kolekcję sztuki Muzeum Okręgowego im. Leona Wyczółkowskiego w Bydgoszczy. Katalog wystawy, red. Elżbieta Kantorek (Bydgoszcz: Muzeum Okręgowe im. Leona Wyczółkowskiego w Bydgoszczy, 2012), 40. 
należała do GPP, jej pokaz traktowano jako gościnny ${ }^{83}$; musiała być jednak bardzo mocno identyfikowana z miastem, skoro w wykazie artystów biorących udział w wystawie przy jej nazwisku napisano „Bydgoszcz” ${ }^{84}$. W lokalnej prasie codziennej pojawiła się przychylna opinia na temat wystawy. Wandę Gentil-Tippenhauer, która tym razem zaprezentowała górskie krajobrazy, m.in. Tatry w zimie oraz Raj narciarzy, okrzyknięto „subtelną akwarelistką" ${ }^{85}$.

\section{Prace artystki - nie tylko w zbiorach bydgoskiego Muzeum}

Zbiory Muzeum Miejskiego sukcesywnie się powiększały, najczęściej dzięki darowiznom. Kiedy finanse muzeum na to pozwalały, kupowano wybrane dzieła sztuki, w lwiej części po zakończeniu ekspozycji, na których artyści prezentowali swój dorobek twórczy. Dla plastyków, obok uczestnictwa w prestiżowej wystawie, była to także okazja do zarobienia pieniędzy, niezbędnych do życia i kontynuowania pracy artystycznej ${ }^{86}$.

Po wystawie „Malarstwo Kazimierza Stabrowskiego i Wandy Gentil-Tippenhauer” zbiory muzealne powiększyły się o dwie zakupione 19 stycznia 1928 roku prace Gentil-Tippenhauer: akwarelę Kanał w Bydgoszczy ${ }^{87}$ i batikową chustę ${ }^{88}$. Najprawdopodobniej po „Wystawie obrazów i grafiki artystek-malarek pp. A. Czarnowskiej, W. Gentil-Tippenhauer i Z. Gerżabek-Małachowskiej oraz grafiki z nowego zakupu" w posiadaniu muzeum znalazł się drugi obraz Gentil-Tippenhauer: Giewont. Po kilku latach, 1 kwietnia 1932 roku bydgoska instytucja nabyła kolejną akwarelę malarki - Dolinę Białej

83 Prezentowane akwarele: Hala Chochołowska, Szałas, Szałas, Tatry w zimie, Raj narciarzy, Zaśnieżona hala, zob. Grupa Plastyków Pomorskich (Bydgoszcz: Muzeum Miejskie w Bydgoszczy, 1934-1935), b.p.; MOB, Biblioteka, Doroczna Wystawa Grupy Plastyków Pomorskich, sygn. 63, Informacja do prasy Muzeum Miejskiego o wystawie „Grupy Plastyków Pomorskich” z dn. 12 XII 1934, b.p.; Borowska, „Wystawy Związku Plastyków Pomorskich,” 152.

84 MOB, Biblioteka, Doroczna Wystawa Grupy Plastyków Pomorskich, sygn. 63, Grupa Plastyków Pomorskich wystawa doroczna, Muz. Nr. 285/34, b.p.

85 (hak) [Henryk Kuminek], „Wystawa Grupy Plastyków Pomorskich,” Dziennik Bydgoski, 6 stycznia 1935,8 .

86 Hojka, Muzeum w Bydgoszczy, 18-22.

87 MOB, Dział Sztuki, Nad kanałem, Wanda Gentil-Tippenhauer, nr inw. MOB MW-413, karta naukowa zabytku, oprac. Elżbieta Kantorek, Bydgoszcz 1978; Staniszewska, „Gentil-Tippenhauer Wanda Anna," 305.

88 W inwentarzu muzealnym figuruje nazwa: Szal; MOB, Dział Historii, Chusta, Wanda Gentil-Tippenhauer, nr inw. MOB H-917, karta naukowa zabytku, oprac. Danuta Sójkowska, Bydgoszcz 2017; MOB, Biblioteka, Działalność Muzeum 1923-1945 (pisma różne), Obrazy zakupione dla Muzeum Miejskiego sezon 1927/1928, b.p.; MOB, Biblioteka, XXIII Wystawy, Ausstellungen, sygn. 40, Pismo Jarockiego do Wandy Gentil-Tippenhauer z 12 I 1928 r., b.p. 
Wody (1925; il. 11). Przedstawia ona pejzaż górski z potokiem, choinką i kładką ułożoną z brązowych pni sosny; dominują w nim szaro-brązowe kamienie i monumentalne góry w tle, utrzymane w kremowo-szaro-błękitnej tonacji. Na drugim planie, pośrodku kompozycji widać drogę biegnącą między rozłożystymi, zielonymi świerkami. W partii nieba i wody w strumieniu autorka pozostawiła oryginalną barwę papierowego podłoża. Praca jest sygnowana w prawym dolnym rogu: Wanda Gentil-Tippenhauer; na odwrociu zachowała się nalepka „Stadtmuseum Bromberg” 89.

W obecnych zbiorach Muzeum Okręgowego im. Leona Wyczółkowskiego w Bydgoszczy brakuje jednej pracy Gentil-Tippenhauer, a mianowicie Giewontu. Akwarelę tę umieszczono na liście strat wojennych Muzeum Miejskiego - uznaje się ją za dzieło utracone. W czasie okupacji, kiedy placówka przeszła w ręce niemieckie, została ona użyczona bydgoskiemu burmistrzowi i nigdy nie wróciła do prawowitego właściciela ${ }^{90}$.

Współcześnie dzieła Wandy są częścią zbiorów przede wszystkim Muzeum Tatrzańskiego im. dr. Tytusa Chałubińskiego w Zakopanem, ale także Muzeum Narodowego w Warszawie, Muzeum Sztuki w Łodzi oraz wspomnianego już Muzeum Okręgowego im. Leona Wyczółkowskiego w Bydgoszczy91. Mogą one również stanowić własność innych placówek muzealnych i galerii, a z pewnością znajdują się w posiadaniu osób prywatnych - Jadwigi i Maksymiliana Misztalów z Zakopanego ${ }^{92}$. Przedwojenny dorobek twórczy Gentil-Tippenhauer doznał olbrzymiego uszczuplenia podczas Powstania Warszawskiego. Warto zaznaczyć, że jedyna znana dzisiaj akwarela malarki, która przedstawia motyw bydgoski, zachowała się w zasobie Muzeum Okręgowego - jest to Kanał w Bydgoszczy. Znane są wprawdzie - odnotowane w katalogach wystaw i dokumentach - wykazy tytułów prac Gentil-Tippenhauer, na których artystka uwieczniła bydgoskie widoki, lecz obecnie nie jest możliwe przeprowadzenie ich analizy ikonograficznej ani formalnej. Pozostaje

89 MOB, Dział Sztuki, Dolina Białej Wody, Wanda Gentil-Tippenhauer, nr inw. MOB MW-412, karta naukowa zabytku, oprac. Elżbieta Kantorek, Bydgoszcz 1978. Opis obrazu konsultowany z historykiem sztuki dr Moniką Kosteczko-Grajek z Bydgoszczy.

90 „Straty wojenne Muzeum Miejskiego w Bydgoszczy, Giewont, Wanda Gentil-Tippenhauer, dawna numeracja O 00320," http://www.stratywojenne.muzeum.bydgoszcz.pl/straty/giewont, dostęp 27 listopada 2020.

91 Informacje uzyskane na podstawie przeprowadzonych w latach 2019-2020 kwerend we wszystkich wymienionych muzeach. W Muzeum Narodowym Ziemi Przemyskiej w Przemyślu nie ma prac Gentil-Tippenhauer (kwerenda z 30 sierpnia 2021 r.).

92 Szatkowski, ,Józef Oppenheim,” 425; Wojciech Szatkowski, „'Ruda' Wanda - z Haiti,” https:// muzeumtatrzanskie.pl/ruda-wanda-z-haiti-do-zakopanego/, dostęp 16 lipca 2020. 
wszakże nadzieja, że jakaś część międzywojennych akwarel, kilimów, batików artystki jednak przetrwała zawieruchę wojenną i zostaną one odzyskane dla polskiego dziedzictwa kulturowego.

\section{Podsumowanie}

Wanda Gentil-Tippenhauer pod wieloma względami była typową polską malarką tworzącą w okresie międzywojennym. Uprawiała dziedziny sztuki i skupiała się na tematach, którymi wtedy najczęściej zajmowały się artystki, brała udział w wielu wystawach, podróżowała. Wyróżniała ją jednak spośród rodzimych malarek jej nieprzeciętna osobowość, ciekawy, a wręcz barwny życiorys i niebanalne w tamtym czasie zainteresowania. Ludziom, którzy ją poznali, musiała wydawać się oryginalna, nawet egzotyczna: kobieta urodzona na dalekiej Haiti, córka pisarki i tłumaczki, z obco brzmiącym podwójnym nazwiskiem (Gentil - francuskie i Tippenhauer - niemieckie) ${ }^{93}$, o niesłowiańskiej urodzie, a do tego inteligentna i utalentowana malarka, wykorzystująca różnorodne formy wyrazu, kochająca polskie góry, narciarstwo, ale przede wszystkim ludzi, zakopiańska działaczka kulturalna i społeczna, autorka wielu tekstów krytycznych i o charakterze wspomnieniowym, wierna przyjaciółka Oppenheima. Te wszystkie elementy składały się na spójną, niezwykłą całość - „Rudą Wandę”.

W Bydgoszczy artystka mieszkała, a potem często tutaj przyjeżdżała. Jak wynika z zachowanych dokumentów, Muzeum Miejskiemu zależało na jej udziale w organizowanych przedsięwzięciach wystawienniczych, jej prace chętnie eksponowano, a później nabywano do muzealnych zbiorów. Chociaż w połowie 1924 roku przeprowadziła się do Warszawy, w mieście nad Brdą nadal traktowano ją jako bydgoszczankę, „swoją”, lokalną plastyczkę. Nieprzypadkowy przecież był jej udział w wystawie trzech „bydgoskich” artystek w 1932 roku. Z prowadzonej przez muzeum korespondencji wynika, że malarka z przyjemnością odwiedzała Bydgoszcz, osobiście odwoziła swoje dzieła na wystawy, przy tej okazji goszcząc u swojej matki w domu przy ul. Zamojskiego. Dzięki temu bydgoszczanie mieli sposobność szerszego poznania jej dorobku artystycznego, a sama Gentil-Tippenhauer - uczestniczenia w kształtowaniu tutejszej plastyki. Sentyment, jakim darzyła miasto nad Brdą, ,zapisany” jest także w tematach i tytułach jej akwarel. Malowała

93 Karnkowska z Bartoszewiczów, „Wspomnienia,” 78. 
najbardziej charakterystyczne dla Bydgoszczy widoki, miejsca, architekturę, co świadczy, że była zaznajomiona ze specyfiką portretowanego miasta, orientowała się, które obszary i obiekty są dla bydgoszczan ważne i inspirujące, z którymi się utożsamiają.

Silne związki Wandy Gentil-Tippenhauer z Bydgoszczą i Muzeum Miejskim oraz znajdująca się w jego zbiorach spuścizna artystki z okresu międzywojennego obligują obecne Muzeum Okręgowe im. Leona Wyczółkowskiego do kultywowania pamięci o tej (nie)zwykłej malarce - jednej z niewielu artystek, które współtworzyły bydgoską plastykę. Nieobecna dotąd w świadomości mieszkańców Bydgoszczy malarka i jej twórczość są na nowo odkrywane i przywracane miejscowej kulturze. Pierwszym krokiem w tym kierunku była zorganizowana w marcu 2020 roku wystawa posterowa „Zasłuż(one) niepodległej Bydgoszczy”, na której przedstawiono biogram Wandy Gentil-Tippenhauer oraz jej dokonania artystyczne ${ }^{94}$.

94 Autorką wystawy, którą zorganizowano dzięki współpracy Miasta Bydgoszczy i Muzeum Okręgowego im. Leona Wyczółkowskiego, była pisząca te słowa kustosz i kierownik Działu Historii MOB. Projekt zrealizowano w ramach obchodów 100. rocznicy powrotu Bydgoszczy do Polski, zob. Monika Komisarek, „Wzbogaciły historię niepodległej Bydgoszczy. Zostały wyróżnione na wystawie, TVP3 Bydgoszcz,” https://bydgoszcz.tvp.pl/47005265/sylwetki-16-kobiet-zasluzonych-dla-bydgoszczy, dostęp 28 listopada 2020. 


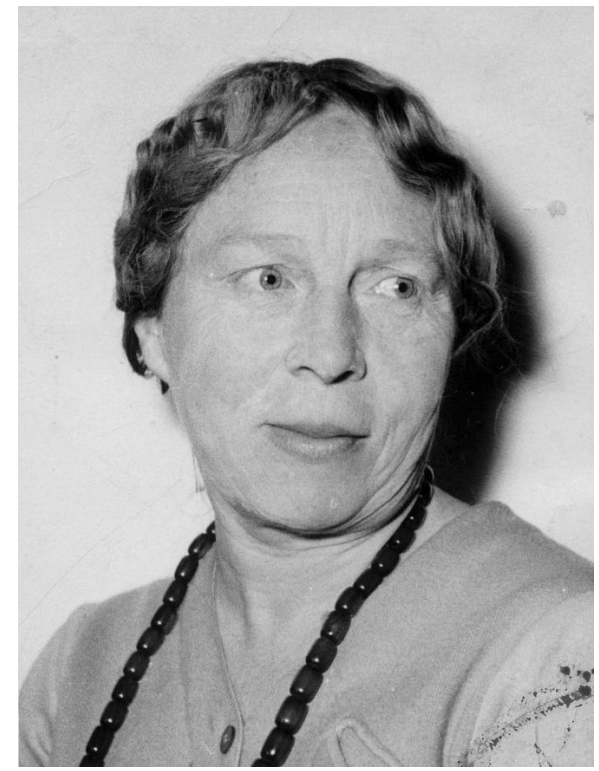

Il. 1. Wanda Gentil-Tippenhauer, po 1945 r. Fot. ze zbiorów J. i M. Misztalów (zdjęcie uzyskane dzięki W. Szatkowskiemu)

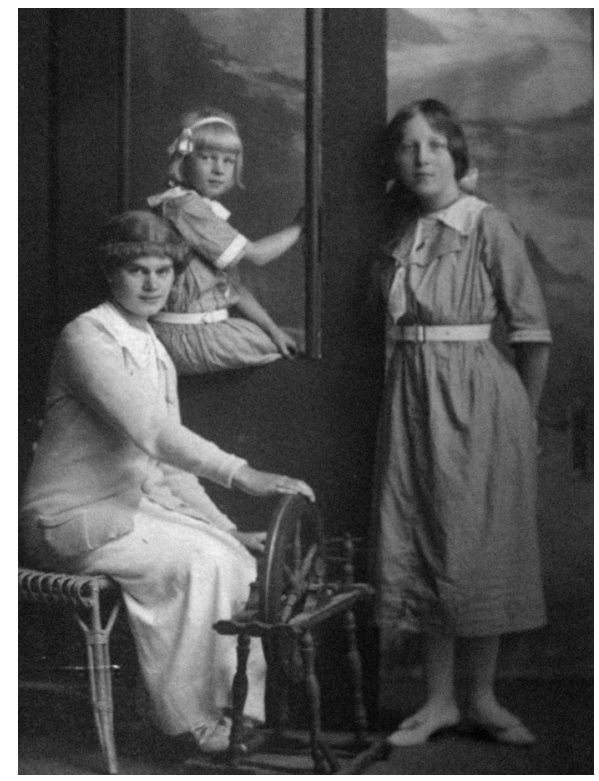

Il. 2. Wiktoria Gentil-Tippenhauer z córkami Wandą i Jadwigą, pocz. XX w. Fot. ze zbiorów J. i M. Misztalów (zdjęcie uzyskane dzięki W. Szatkowskiemu) 


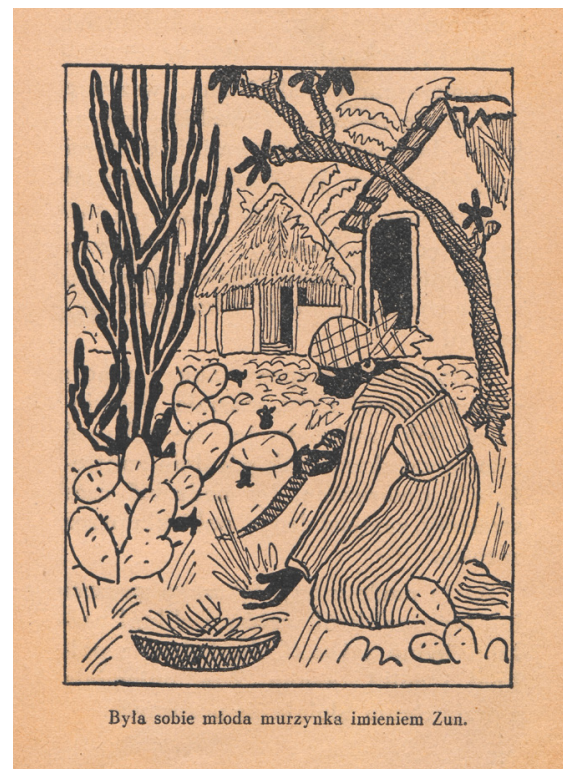

Il. 3. Ilustracja Wandy Gentil-Tippenhauer w książce Wiktorii Gentil-Tippenhauerowej Bajki murzyńskie z Haiti, Warszawa 1931, s. 85. Fot. A. Nadolska

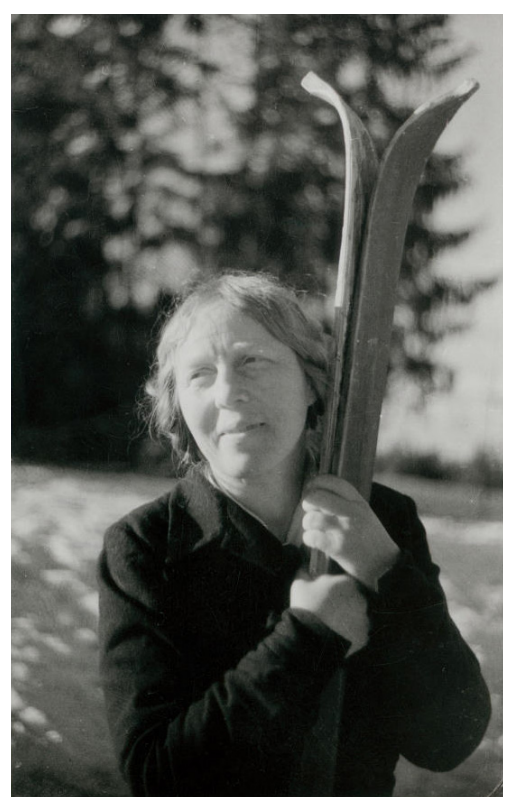

Il. 4. Wanda Gentil-Tippenhauer, Zakopane, po 1945 r. Fot. ze zbiorów J. i M. Misztalów (zdjęcie uzyskane dzięki W. Szatkowskiemu) 


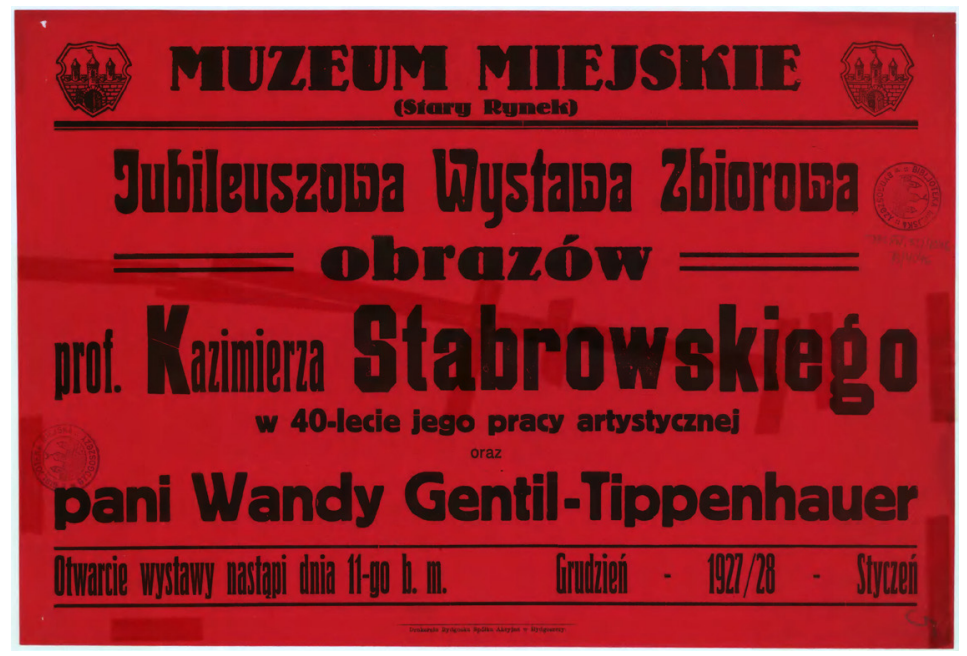

Il. 5. Afisz „Jubileuszowej Wystawy Zbiorowej obrazów prof. Kazimierza Stabrowskiego w 40-lecie jego pracy artystycznej i pani Wandy Gentil-Tippenhauer”, Muzeum Miejskie w Bydgoszczy, 1927. Fot. ze zbiorów Wojewódzkiej i Miejskiej Biblioteki Publicznej im. dr. Witolda Bełzy w Bydgoszczy, Zbiory Specjalne, nr inw. DŻS XIV.3.2/4076

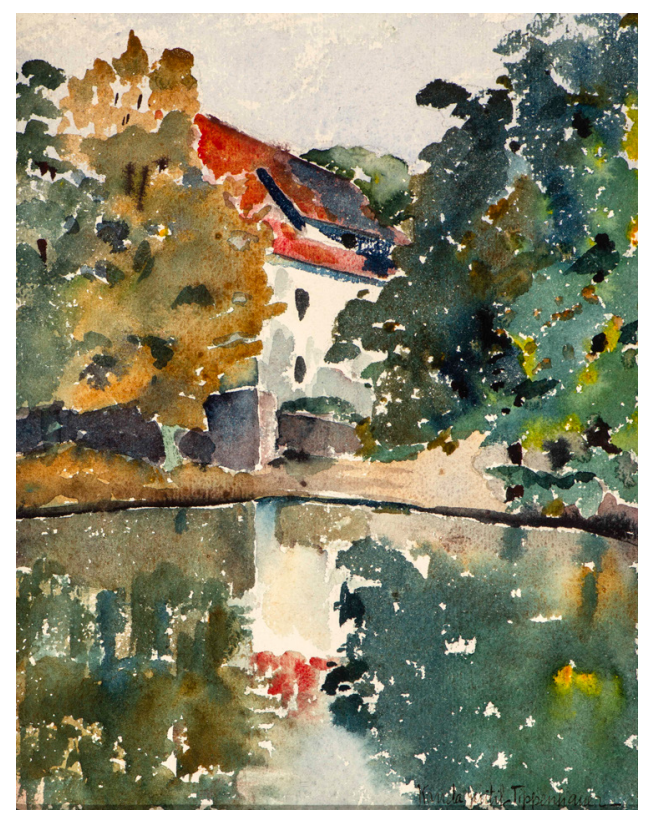

Il. 6. Kanat w Bydgoszczy (Nad kanałem), Wanda Gentil-Tippenhauer, akwarela, 1925. Fot. ze zbiorów Muzeum Okręgowego im. Leona Wyczółkowskiego w Bydgoszczy, Dział Sztuki, nr inw. MOB MW-413. Fot. W. Woźniak 


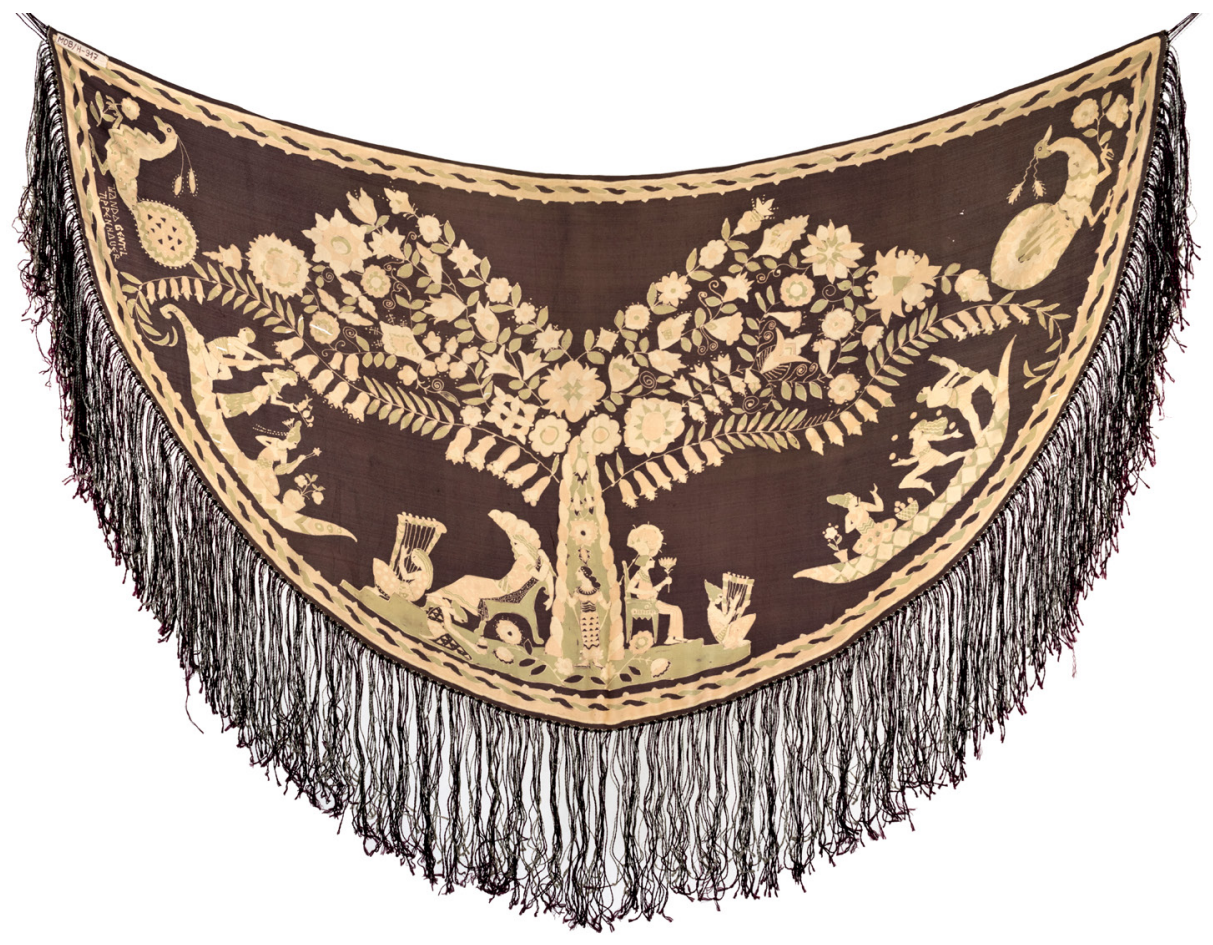

Il. 7. Chusta, Wanda Gentil-Tippenhauer, jedwab, batik, lata 20. XX w. Fot. ze zbiorów Muzeum Okręgowego im. Leona Wyczółkowskiego w Bydgoszczy, Dział Historii, nr inw. MOB H-917. Fot. W. Woźniak 


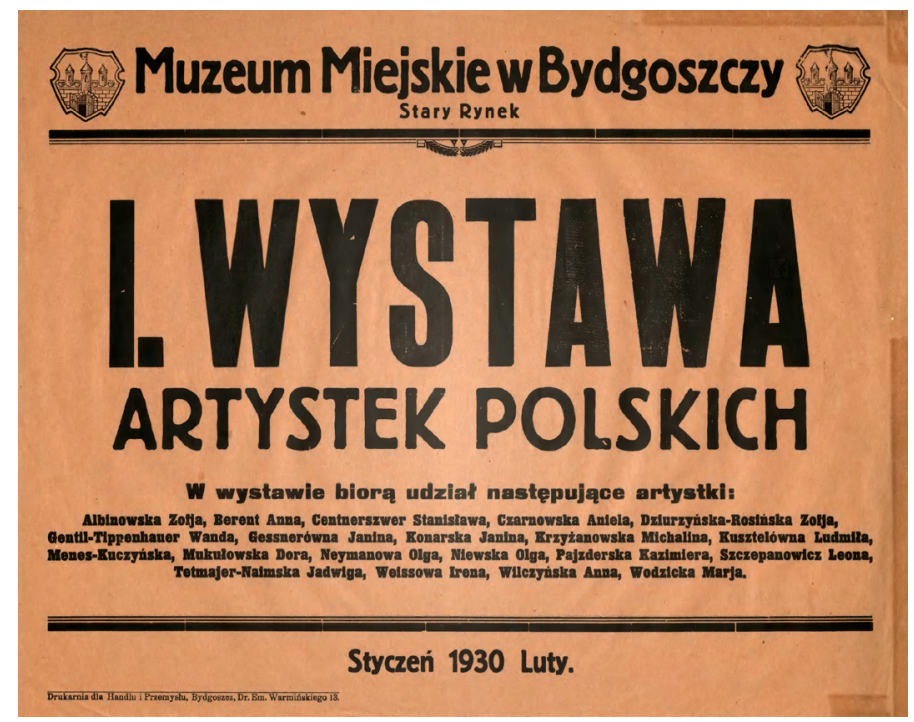

Il. 8. „I Wystawa artystek polskich”, Muzeum Miejskie w Bydgoszczy, afisz, 1930. Fot. ze zbiorów Wojewódzkiej i Miejskiej Biblioteki Publicznej im. dr. Witolda Bełzy w Bydgoszczy, Zbiory Specjalne, nr inw. DŻS XIV.3.2/4088

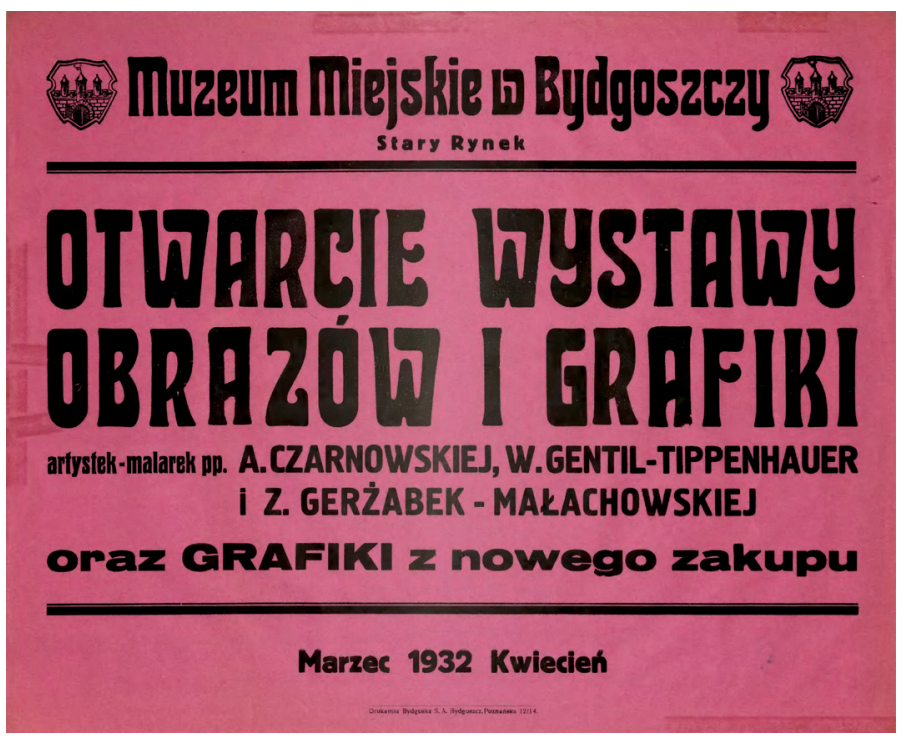

Il. 9. „Otwarcie wystawy obrazów i grafiki artystek-malarek pp. A. Czarnowskiej, W. Gentil-Tippenhauer i Z. Gerżabek-Małachowskiej oraz grafiki z nowego zakupu”, afisz, 1932. Fot. ze zbiorów Wojewódzkiej i Miejskiej Biblioteki Publicznej im. dr. Witolda Bełzy w Bydgoszczy, Zbiory Specjalne, nr inw. DŻS XIV.3.2/4094 


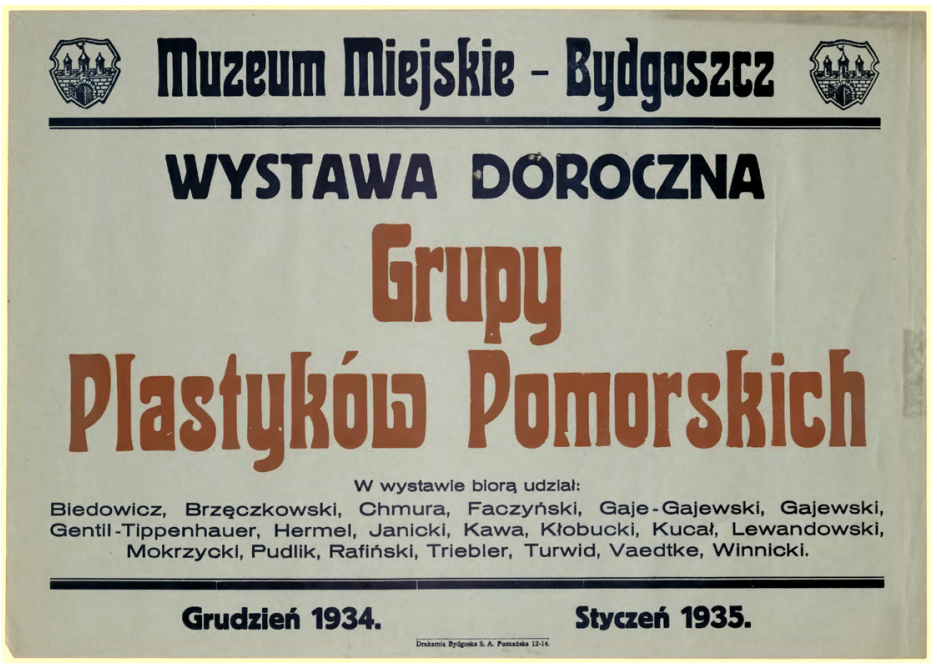

Il. 10. „Wystawa doroczna Grupy Plastyków Pomorskich”, afisz, 1934. Fot. ze zbiorów Wojewódzkiej i Miejskiej Biblioteki Publicznej im. dr. Witolda Bełzy w Bydgoszczy, Zbiory Specjalne, nr inw. DŻS XIV.3.2/4108

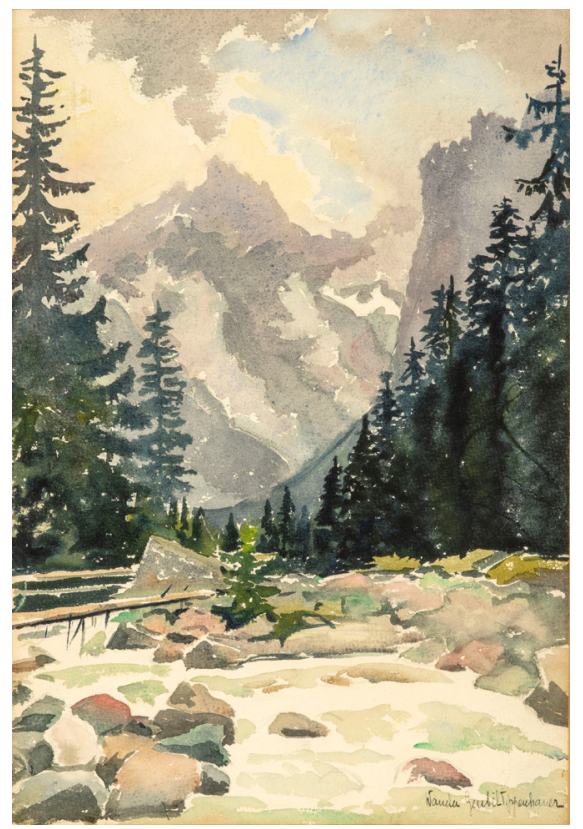

Il. 11. Dolina Białej Wody, Wanda Gentil-Tippenhauer, akwarela, 1925. Fot. ze zbiorów Muzeum Okręgowego im. Leona Wyczółkowskiego w Bydgoszczy, Dział Sztuki, nr inw. MOB MW-412. Fot. W. Woźniak 


\section{Bibliografia}

\section{Źródła archiwalne}

Archiwum Państwowe w Bydgoszczy (APB):

Polskie legalne organizacje, związki, stowarzyszenia, towarzystwa i komitety 1920$-1939,479$, sygn. 28.

Muzeum Okręgowe im. Leona Wyczółkowskiego w Bydgoszczy (MOB), Biblioteka:

Doroczna wystawa Grupy Plastyków Pomorskich, sygn. 63.

Działalność Muzeum 1923-1945 (pisma różne).

Malarstwo Kazimierza Stabrowskiego, Wandy Gentil-Tippenhauer, 11 XII 1927-10 I 1928, sygn. 19.

Pierwsza wystawa artystek polskich, sygn. 32 .

Wykaz teczek z wystawami.

Wystawa obrazów i grafiki artystek-malarek zamieszkałych w Bydgoszczy oraz grafiki zakupionej w ostatnim roku do zbiorów muzeum, 20 III-10 IV 1932, sygn. 45. XXIII Wystawy, Ausstellungen, sygn. 40.

\section{Karty naukowe zabytków}

Muzeum Okręgowe im. Leona Wyczółkowskiego w Bydgoszczy, Dział Historii, Chusta, Wanda Gentil-Tippenhauer, nr inw. MOB H-917, karta naukowa zabytku, oprac. Danuta Sójkowska, Bydgoszcz 2017.

Muzeum Okręgowe im. Leona Wyczółkowskiego w Bydgoszczy, Dział Sztuki, Dolina Białej Wody, Wanda Gentil-Tippenhauer, nr inw. MOB MW-412, karta naukowa zabytku, oprac. Elżbieta Kantorek, Bydgoszcz 1978.

Muzeum Okręgowe im. Leona Wyczółkowskiego w Bydgoszczy, Dział Sztuki, Nad kanałem, Wanda Gentil-Tippenhauer, nr inw. MOB MW-413, karta naukowa zabytku, oprac. Elżbieta Kantorek, Bydgoszcz 1978.

\section{Opracowania}

Adresy miasta Bydgoszczy na rok 1923. Bydgoszcz: Władysław Weber, 1923. Adresy miasta Bydgoszczy na rok 1925. Bydgoszcz: Władysław Weber, 1925. Adresy miasta Bydgoszczy na 1926 rok. Bydgoszcz: Władysław Weber, 1926. Borowska, Marta. „Wystawy Związku Plastyków Pomorskich i Grupy Plastyków Pomorskich w Muzeum Miejskim w Bydgoszczy w latach 1930-1936.” Porta Aurea 17 (2018): 133-161.

Borucki, Kazimierz. „Plastyka bydgoska w latach 1920-1945.” W Bydgoszcz w latach 1920-1970. Materiały z sesji popularnonaukowej, red. Jerzy Konieczny i Edmund Trempała (Prace Popularnonaukowe nr 6), 247-256. Bydgoszcz: Bydgoskie Towarzystwo Naukowe, 1972. 
Cetera-Włodarczyk, Anna, i Alicja Kosim. Polskie przekłady Shakespeare’a w XIX wieku. Cz. I Zasoby, strategie, recepcja. Warszawa: Wydawnictwa Uniwersytetu Warszawskiego, 2019.

Chojnacka, Barbara. „Malarstwo w międzywojennej Bydgoszczy (1920-1939). Zapomniane dziedzictwo?” W Stare i nowe dziedzictwo Torunia, Bydgoszczy i regionu, red. Juliusz Raczkowski i Monika Jakubek-Raczkowska (Studia i Materiały z Dziedzictwa Kulturowego Torunia i Regionu 2), 175-198. Toruń: Wydział Sztuk Pięknych Uniwersytetu Mikołaja Kopernika w Toruniu, 2018.

Chojnacka, Barbara. „Od bydgoskiej 'Zachęty’ do 'Salonów Bydgoskich.' Związki i grupy artystyczne w latach 1921-1939.” W 100 lat Związku Polskich Artystów Plastyków. Zaczęło się w Krakowie w roku 1911. Historia ZPAP 1911-1939 w oparciu o kolekcję sztuki Muzeum Okręgowego im. Leona Wyczótkowskiego w Bydgoszczy. Katalog wystawy, red. Elżbieta Kantorek, 35-43. Bydgoszcz: Muzeum Okręgowe im. Leona Wyczółkowskiego w Bydgoszczy, 2012.

Dział Sztuki: Powszechna Wystawa Krajowa. Poznań: Powszechna Wystawa Krajowa, 1929.

Gentil-Tippenhauerowa, Wiktoria. Bajki murzyńskie z Haiti. Warszawa: „Polska Zjednoczona," 1931.

Grupa Plastyków Pomorskich. Bydgoszcz: Muzeum Miejskie w Bydgoszczy, 1934-1935.

Hojka, Zdzisław. Muzeum w Bydgoszczy. Dzieje i zbiory (Od kościoła Klarysek po Wyspę Młyńską. Muzeum w Bydgoszczy 1923-2008, t. 1, red. Michał Woźniak). Bydgoszcz: Muzeum Okręgowe im. Leona Wyczółkowskiego, 2008.

Jakubowska, Agata. „Historia wystaw sztuki kobiet w Polsce. Wstęp.” Sztuka i Dokumentacja 15 (2016): 7.

Katalog Galerji Miejskiej, wystawa czerwiec-wrzesień 1929. Bydgoszcz: Muzeum Miejskie w Bydgoszczy, 1929.

Katalog ilustrowany Miejskiej Galerji obrazów i rzeźb w Bydgoszczy. Bydgoszcz: Muzeum Miejskie, 1929.

Katalog jubileuszowej wystawy zbiorowej obrazów prof. Kazimierza Stabrowskiego w 40-lecie jego pracy artystycznej oraz p. Wandy Gentil-Tippenhauer, grudzień 1927. Bydgoszcz: Muzeum Miejskie w Bydgoszczy, 1927.

Katalog I Wystawy Artystek Polskich styczeń-luty 1930. Bydgoszcz: Muzeum Miejskie w Bydgoszczy, 1930.

Księga adresowa m. Bydgoszczy 1933 rok. Bydgoszcz: Władysław Weber, 1933.

Księga adresowa miasta Bydgoszczy rocznik 1936/1937. Bydgoszcz: Jan Miernik, 1937.

Kulpińska, Katarzyna. „Studentki szkół artystycznych i artystki w Polsce okresu międzywojennego - wybrane aspekty profesji.” Acta Universitatis Lodziensis. Folia Sociologica 66 (2018): 33-53.

Morawińska, Agnieszka. „Malarki polskie między wojnami.” W Równe prawa i nierówne szanse. Kobiety w Polsce międzywojennej, red. Anna Żarnowska i Andrzej Szwarc, 255-269. Warszawa: Wydawnictwo DiG, 2000. 
Mrozek, Zdzisław. „Polska kultura i sztuka w Bydgoszczy w latach 1920-1939.” W Historia Bydgoszczy. T. 2, cz. 1 1920-1939, red. Marian Biskup, 719-781. Bydgoszcz: Bydgoskie Towarzystwo Naukowe, 1999.

Oppenheim, Józef. Szlaki narciarskie Tatr Polskich i główne przejścia na południową stronę. Kraków: Polski Związek Narciarski, 1936.

Polska Bydgoszcz 1920-1930. Dziesięć lat pracy twórczej (Wydawnictwo Jubileuszowe). Bydgoszcz: Komitet Obchodu Dziesięciolecia Oswobodzenia Miasta Bydgoszczy, 1930.

Przewodnik po wystawie Towarzystwa Zachęty Sztuk Pięknych, nr 51. Warszawa: Towarzystwo Zachęty Sztuk Pięknych w Warszawie, 1930.

Shakespeare, William. Romeo i Julia. Tragedya w 5 aktach. Tłum. Wiktorya Rosicka. Łódź: Księgarnia L. Fischera, 1892.

Sieradzka, Anna. „Nie tylko Stryjeńska. Udział kobiet-artystek w tworzeniu stylu art déco w Polsce." W Kobieta i kultura. Kobiety wśród twórców kultury intelektualnej $i$ artystycznej $w$ dobie rozbiorów $i$ w niepodległym państwie polskim. Zbiór studiów. T. 4, red. Anna Żarnowska i Andrzej Szwarc, 203-210. Warszawa: Wydawnictwo DiG, 1996.

Sosnowska, Joanna. Poza kanonem. Sztuka polskich artystek 1880-1939. Warszawa: Instytut Sztuki PAN, 2003.

Staniszewska, Anna. „Gentil-Tippenhauer Wanda Anna.” W Słownik artystów polskich i obcych $w$ Polsce działających. Malarze, rzeźbiarze, graficy. T. 2 D-G, red. Jolanta Maurin-Białostocka et al., 304-305. Wrocław-Warszawa-Kraków-Gdańsk: Instytut Sztuki Polskiej Akademii Nauk / Zakład Narodowy im. Ossolińskich, 1975.

Szatkowski, Wojciech. Józef Oppenheim, przyjaciel Tatr i ludzi. Zakopane-Łomianki: Muzeum Tatrzańskie / Wydawnictwo LTW, 2021.

Teichert, Małgorzata. „Wanda Anna Gentil-Tippenhauer.” W Artystki polskie. Katalog wystawy, red. Agnieszka Morawińska, 161. Warszawa: Muzeum Narodowe w Warszawie, 1991.

Zientara, Maria. „Artystki polskie i ich sztuka w latach 1900-1939. Część I. Nurt narodowej sztuki dekoracyjnej.” Krzysztofory. Zeszyty Naukowe Muzeum Historycznego Miasta Krakowa 25 (2007): 149-170.

\section{Artykuły prasowe}

„Bydgoszcz w Zachęcie Warszawskiej.” Gazeta Bydgoska, 2 października 1923, 4.

Gentil-Tippenhauer, Wanda. „Kościół w Szaradowie.” Gazeta Bydgoska, 12 września 1926, 6.

(hak) [Kuminek, Henryk]. „Wystawa Grupy Plastyków Pomorskich.” Dziennik Bydgoski, 6 stycznia 1935, 8.

(hak) [Kuminek, Henryk]. „Wystawa plastyków pomorskich dowodem żywotności kulturalnej regjonu.” Dziennik Bydgoski, 19 grudnia 1934, 8. 
„Kronika. Wystawa artystek polskich.” Dziennik Bydgoski, 26 stycznia 1930, 1, 12. „Koncert piątkowy.” Dziennik Bydgoski, 17 stycznia 1922, 3.

„Otwarcie nowej wystawy w Muzeum Miejskim.” Gazeta Bydgoska, 22 marca 1932, 7.

S.P.O. [Stefania Podhorska-Okołów]. „Malarstwo Wandy Gentil-Tippenhauer.” Bluszcz.

Społeczno-Literacki Tygodnik Kobiecy 50 (1938): 2 (1246).

„Wystawa artystek polskich.” Gazeta Bydgoska. Kurjer Bydgoski, 26 stycznia 1930, 6.

„Wystawa malarek i rzeźbiarek.” Gazeta Bydgoska. Kurjer Bydgoski, 28 stycznia 1930, 5.

„Wystawa obrazów.” Dziennik Bydgoski, 12 kwietnia 1922, 3.

Z. M. [Zygmunt Malewski]. „Wystawa artystek polskich.” Dziennik Bydgoski, 4 lutego 1930, 5.

„Z Muzeum Miejskiego.” Dziennik Bydgoski, 13 grudnia 1927, 8.

„Z Muzeum Miejskiego.” Dziennik Bydgoski, 9 kwietnia 1932, 10.

\section{Netografia}

Karnkowska, Maria z Bartoszewiczów. „Wspomnienia cz. I i II.” Wydano przez Kazimierza Karnkowskiego, Baden CH-5400 - czerwiec 2013. Dostęp 14 lipca 2020. file://C:/Users/Ania/Desktop/Maria\%20Karnkowska\%20Wspomnienia\%20(1).PDF.

Komisarek, Monika. „Wzbogaciły historię niepodległej Bydgoszczy. Zostały wyróżnione na wystawie. TVP 3 Bydgoszcz.” Dostęp 28 listopada 2020. https://bydgoszcz.tvp. pl/47005265/sylwetki-16-kobiet-zasluzonych-dla-bydgoszczy.

Król, Klaudia. „Zakopiańskie love story. Portal Tatrzański.” Dostęp 29 listopada 2020. https://portaltatrzanski.pl/wiedza/historia/zakopianskie-love-story,1651.

„Polski Szekspir.” Dostęp 8 marca 2021. http://polskiszekspir.uw.edu.pl/tlumacze

Radziewicz, Joanna. „Batik - z Indonezji do Polski.” Dostęp 7 września 2021. https:// rme.cbr.net.pl/index.php/archiwum-rme/739-listopad-grudzien-nr-82/kultura-i-tradycje-ludowe/1102-batik-z-indonezji-do-polski.

„Straty wojenne Muzeum Miejskiego w Bydgoszczy. Giewont, Wanda Gentil-Tippenhauer, dawna numeracja O 00320.” Dostęp 27 listopada 2020. http://www.stratywojenne.muzeum.bydgoszcz.pl/straty/giewont/.

Szatkowski, Wojciech. „'Ruda’ Wanda i ‘Opcio’. Love story z Pysznej?” Dostęp 28 sierpnia 2021. http://archiwalna.muzeumtatrzanskie.pl/UserFiles/File/PDF/Ruda_Wanda_i_Opcio_Love_story_z_Pysznej.pdf.

Szatkowski, Wojciech „'Ruda’ Wanda - z Haiti do Zakopanego.” Dostęp 16 lipca 2020. https://muzeumtatrzanskie.pl/ruda-wanda-z-haiti-do-zakopanego/.

„Wystawa: I Wystawa artystek polskich. Wystawy sztuki kobiet.” Dostęp 16 czerwca 2018. http://wystawykobiet.amu.edu.pl/wystawa/i-wystawa-artystek-polskich,33.html. 